\title{
AZ ÚJ VALLÁSI KÖZÖSSÉGEK LÉTREJÖTTÉNEK MAGYARORSZÁGI OKAI A XXI. SZÁZAD ELEJÉN
}

\author{
RIXER ÁDÁM
}

\begin{abstract}
The Reasons behind the Establishment of Newly Created Religious Communities in Hungary in the $21^{\text {st }}$ century

In this paper three dimensions of the newly created religious entities in Hungary will be discussed. Firstly, the main reasons of their establishment, secondly, the organisational formats, including the legal forms, and thirdly, the new and special activities pursued by them. Our analysis shows mainly the creation and transformation of Christian communities during the last three decades, but, in some important cases, earlier processes and facts are also mentioned.

This work primarily applies the approaches and methods of legal studies and sociology, but also makes use of the views and findings of political science and other fields, and the results of this paper can thereby be considered to have come from a consciously complex approach.

Although a broad range of scientific literature can be detected related to this topic, they mainly introduce only one or just a few aspects of this phenomenon, or concentrate on one certain community. My paper tends to be the first general attempt at a structured approach, an initial overview which must be followed by more detailed ones.
\end{abstract}

\section{A TANULMÁNY CÉLJAI, A KUTATÁS KERETE}

A lelkiismereti és vallásszabadság jogáról, valamint az egyházak, vallásfelekezetek és vallási közösségek jogállásáról szóló 2011. évi CCVI. törvény (a továbbiakban: Ehtv.) 6. \$-a értelmében „Vallási közösség a természetes személyek minden olyan közössége, szervezeti formától, jogi személyiségtől vagy elnevezéstől függetlenül, amely vallás gyakorlására alakult, és elsődlegesen vallási tevékenységet végez”. Jelen tanulmány egyik fö célja a közelmúltban Magyarországon létrejött új keresztény vallási közösségek vizsgálata, a lehetséges okok és a müködés egyes sajátosságainak 
elemzése révén. Már elöljáróban rögzíthetjük, hogy a vallási közösség kifejezést - a jogalkotói megközelítéssel egyezően - a lehető legtágabb értelemben használjuk, a jogi formákat öltő entitásokon túl a mozgalmi jellegü, illetve eseti törekvéseket is vizsgálat tárgyává téve. Sőt, ezzel részben reagálunk is a mozgalmiság egyik új formájára, az „egyszemélyes mozgalmak” megjelenésére, amennyiben a növekvő számban jelen lévő, a „maguk módján vallásos”, egyházhoz stb. nem tartozó személyek törekvései is egy sajátos irányt jelölnek ki, valamifajta extrém, „kapcsolatok nélküli mozgalmiság" kontúrjait öltve.

A szakirodalomban ismertek azok az elképzelések is, amelyek például szektának nevezik az elszakadó, kultusznak pedig az új keletkezésű vallási entitásokat, ${ }^{1}$ de ezen fogalmak beemelése és következetes használata nem jár különösebb elönyökkel - így maradunk a vallási közösség kifejezésnél, mégpedig annak tudatosan széles jelentéstartományánál.

Noha a tanulmány tárgykörében jelentősnek mondható az újabb nemzetkö$\mathrm{zi}^{2}{ }^{2}$ hazai ${ }^{3}$ és határon túli magyar ${ }^{4}$ szakirodalom, valamint a hazai fejleményekre is hatást gyakorló nemzetközi vonatkozásokat bemutató irodalom, a változásokat és azok okait és gyakorlati formáit rendszerezni kívánó katalógus összeállítására mindeddig nem került sor - inkább csak egy vagy legfeljebb néhány szempont kiemelése és a szféra egészének ennek mentén történő vizsgálata, illetve egy-egy vallási entitás bemutatása bővítette a felhasználható irodalmak körét.

Az új, azonosítható szervezettel, illetve mozgalmi jellegü, gyakran amorf, elnagyolt kontúrokkal rendelkező vallási csoportok/közösségek létrejöttének, kialakulásának mögöttes okait katalogizáljuk tehát a továbbiakban, rögzítve, hogy alapozó jellegü kutatásról van szó, amely egyként igényli az egyes feltárt elemek pontosítását és részletgazdagabb kifejtését a középtávoli jövőben, a további - a jogi és szűkebben vett vallástudományi megközelítéseken túl más diszciplínák eredményeit is bevonzó - kutatások alkalmával.

\footnotetext{
${ }^{1}$ Rodney Stark - S. William Bainbridge: The Theory of Religion. New York, Peter Lang, 1987.

${ }^{2}$ Lásd például: Caroline M. Cusack - Danielle L. Kirby (szerk.): Sects, Cults, and New Religions. London, Routledge, 2014.

${ }^{3}$ Csupán a legismertebb munkák közül említve néhányat: Rajki Zoltán - Szigeti Jenő: Szabadegyházak története Magyarországon 1989-ig. Budapest, Gondolat, 2012; Lugosi Győző: „Szekták, kultuszok, (már nem is annyira) új vallási mozgalmak... Szcientológia és globalizáció.” Eszmélet, XXIX, 2017/2, 190-211; Simon Zoltán: „Megjegyzések az erdélyi szabadegyházak, új vallási mozgalmak kutatásának margójára. A szektaképződés kérdésköre az antropológiai kutatás gyakorlatában.” Szellem és Tudomány, XI, 2020/Klnsz. 578-587.

${ }^{4}$ Kiss Dénes: „Deszekularizáció Romániában.” Korunk, XXV, 2014/5, 4-14.
} 
A jelen tanulmány által vizsgált időszak a mögöttünk hagyott mintegy három évtized - azzal a megjegyzéssel, hogy néhány esetben egyes folyamatok kiváltó okai, objektív társadalmi vagy elszigetelt, jogi típusú változásai korábbi tények felvetését és elemzését is szükségessé teszik. Elemzésünk döntően a keresztény jellegü, hátterü csoportokra (közösségekre) vonatkozóan él a következtetések levonásának lehetőségével, azzal az előfeltevéssel élve, hogy ezek jelentősége kiemelkedő, így az ezekre szükített célzott vizsgálat előnyei meghaladhatják a teljeskörűségre törekvő, ámde elnagyoltabb megközelítések révén nyerhető elönyöket.

Jelezni kívánjuk továbbá, hogy jelen munka célja azoknak a jogtudomány, politikatudomány, szociológia és szűkebben vett vallástudomány által megragadható társadalmi okoknak, hatásoknak, különféle mechanizmusoknak a láttatása és értékelése, melyek nyomán közösségek alakulnak át, illetve jönnek létre: a teológia érvei és a bibliai alapok ismertetése e munkának nem jellegadó eleme - miközben valljuk az isteni teremtés tényét és Istennek az ember életében való folyamatos jelenlétét.

Itt érdemes megjegyeznünk, hogy önállóan és részletekbe menően nem kívánjuk bemutatni azokat a globális természetű társadalmi folyamatokat, melyek általános hatása mindenütt érvényesül a fejlett, illetve fejlődő világban: így a transzhumanista eszmék és társadalomalakító gyakorlatok által is felerösített elidegenedésről, vagy éppen az annak ellenhatásaként is felfogható perszonalista koncepciókról és azokat megalapozó, illetve visszatükröző tudományos konstrukciókról részletesen nem írunk. Ezek olvasó általi ismeretét, illetve társadalmi jelenvalóságát adottnak vesszük, azokra egy-egy résztéma kapcsán csak a lehető legszükségesebb mértékben utalunk.

Jelen munka tehát első körben feltárja és csoportosítja az új entitások létrejöttének főbb közvetlen okait, megkülönböztetve a már létező közösségeken belüli „,válóokokat”, ezek vonatkozásában a külső, döntően állami eredetű „kényszerítő körülményeket”, illetve ezektől függetlenül a szervezett előzmények nélküli, „vadonatúj” közösségek létrejöttének kiváltó okait. Külön helyeztük el az ún. egyéb vagy „vegyes” okokat, ezzel biztosítva a viszonylagos teljeskörüséget. Az okok bemutatását követően önálló fejezetben rögzítjük az új közösségek föbb szervezeti és működési formáit, előbbi vonatkozásában kitérve a jogi és nem jogi formákra, utóbbi esetben pedig kiemelve azokat a jellemző tevékenységformákat, melyek a valódi „újdonságot” adják.

A szféra hozzávetőleges méreteit és belső mozgásirányait érzékeltetve elöljáróban néhány adattal szolgálunk, ám már most jelezzük (s később ezt részleteiben is bemutatjuk), hogy a vallási közösségek számából megalapozott következtetések levonása csak egyes további jogi, politikai és gyakorlati szempontok (tények) ismeretében lehetséges. Az azonban bizonyosan lényeges, hogy a '60-as, '70-es évek 
vallási visszaesése (Magyarországon a '30-as évekhez képest nyolcadára csökkent a rendszeresen templomba járók száma) ${ }^{5}$ egyrészt a modernizáció általános tünete, másrészt az állampárt egyházpolitikájának közvetlen következménye. A vallásosság mértékének újbóli hazai növekedése már a '70-es években elindul és a rendszerváltozás táján gyorsulva növekszik (párhuzamosan a vallásukat gyakorlók életkorának lassú csökkenésével (azaz „megfiatalodásával”), majd pedig a vallásosság két irányba ágazik el: az egyházias vallásosság enyhe csökkenése, illetve a „maguk módján” vallásos személyek csoportjának enyhe számbeli növekedése figyelhető meg. ${ }^{6}$ A „plató” 2000 körül jön el: a vallási telítődés jelei figyelhetőek meg a „vallási piacon”; a rendszerváltozás környékén, illetve azt követően megjelenő vallási irányzatok és külföldi „térítők” újdonságának varázsa csökken, illetve a hagyományos egyházak újjászervezésének első lendülete is kifullad. 2012-ben Magyarországon a felnőtt népesség körében a magukat nagyon vallásosnak mondók aránya $7,8 \%$, a valamennyire vallásosaké pedig $28,4 \% .^{7}$

Az egyházias vallásosság körében a már említett visszaesés elsősorban a hagyományos egyházakat (különösen a katolikus egyházat) érintette az elmúlt évtizedekben, a kisebb egyházak stagnálása, illetve szerény növekedése mellett. Mindezen tények együttesen különösen érdekes, sőt izgalmas kérdéssé teszik, hogy mely okok játszanak szerepet az újabb közösségek létrejöttében.

\section{2. ÚJ (KERESZTÉNY) VALLÁSI MOZGALMAK, ILLETVE KÖZÖSSÉGEK LÉTREJÖTTÉNEK FÖBB OKAI}

Vizsgálatunk fő törekvése az együvé tartozó, illetve könnyen egynemüsíthető okok valamennyire homogén okcsoportokba sorolása - még akkor is, ha ez szélesebb terjedelmü elemeket eredményez. Ezek elkülönítése még akkor is indokolt, ha egyébként - egy-egy konkrét esetben - feltárhatóak vegyes, illetve többrétegü folyamatok is - előbbi alatt a szervezet egészét tekintve is több ok jelenlétét valószínüsítve, utóbbi alatt pedig a szervezet egyes szintjeinek, belső egységeinek eltérő okok mentén történő ki- vagy átalakulását értve.

Történeti nézőpontból jól érzékelhető, hogy nagyobb időszakonként léteznek olyan általános - akár teológiai, akár nem teológiai vagy csak annak álcá-

\footnotetext{
${ }^{5}$ Havasi Virág: „Vallási körkép - A vallásosság alakulása itthon és külföldön.” In Szabó-Tóth Kinga - Várhelyi Krisztina (szerk.): A történelmi egyházak - modern társadalom. Budapest, L'Harmattan, 2018, 5; Tomka Miklós: Vallás és társadalom Magyarországon. Budapest-Piliscsaba, Loisir Kft., 2006.

${ }^{6}$ Tomka: Vallás és társadalom, 22.

${ }^{7}$ Havasi: „Vallási körkép”, 21.
} 
zott - okok, melyek az új entitások létrejöttének tipikus és közvetlen okaiként is meghatározhatóak: például régebben inkább a templombelső kialakítása, a zeneszerszámok használata, az Istennel való személyes, közvetítés nélküli kapcsolat lehetősége, szükségessége és terjedelme vagy az egyházi adó mértéke, az annak beszedésére jogosult személye, a vallási elöljáró kinevezésére jogosult személye stb. jelentek meg szempontként..., míg napjainkban inkább a keresztelő szükségessége (persze ennek jelentősége a korábbi vitákban is megfigyelhető), a tagsági feltételek tartalma, az elkötelezettség mértéke, szükségessége, a karizmák mibenléte, jelentősége stb. jelentik az elkülönülés főbb szempontjait. Az általános - tehát a keresztény dominanciájú világrészekre igaz - trendeken és elveken túl azonban éppen a kifejezetten magyarországi okok, esetleges többletokok feltérképezése és rendszerezése e tanulmány egyik fó célja.

Noha a Makkai Sándor által az új „szekták” létrejöttének okait kategorizáló törekvést is tartható álláspontnak látjuk, ${ }^{8}$ a magunk részéről az okcsoportokat egyrészt létező entitásokon belüli hatások, másrészt az intézményes előzmények nélküli kialakulás államtól független okai szerint, harmadrészt az állami fellépéssel összefüggő tényezők, negyedrészt pedig az egyéb vagy vegyes okok szerint különítjük el jelen tanulmányban.

\section{II.1. AZ ELSŐ OKCSOPORT: MEGLÉVŐ SZERVEZETEN BELÜLI (ENDOGÉN) ÉRDEMI OKOK}

Ez talán a legkézenfekvőbb köre az elsődleges okoknak: ezek már meglévő csoportokon belül kifejlődő markáns (tehát nem egyedi, elszigetelt) tanításbeli (teológiai), illetve kifejezetten gyakorlati okok (egyházéleti, egyházszervezési, helyszínnel összefüggő, pl. földrajzi távolságból adódó okok), vagy egyéb személyes, döntően kapcsolati természetű okok ( $a$ „valódi” közösség-igény, többlet-igény kapcsán lásd még a II.2.1. alfejezetet), melyek a meglévő csoportból történő kiválást hozhatnak, $s$ amelyek praktikusan és az esetleges jogi folyamatot is leíró módon a kiválás, szétválás, beolvadás, egyesülés egymásra épülő formáiban eredményezhetik új vallási entitás létrejöttét ${ }^{9}$ - akár azonos elnevezés mellett is. A fenti feltételeken túl új cso-

\footnotetext{
${ }^{8}$ Makkai a szekták keletkezésének okait öt kategóriába sorolja, elkülönítve a teológiai, egyházi (gyülekezeti), társadalmi, lélektani és egyéb tényezőket. Hivatkozza: Fekete Péter: Az egyház és a szekta. Budapest, Magyarországi Református Egyház Kálvin János Kiadója, 1993, 87.

${ }^{9}$ Az elmúlt évtizedek legismertebb hazai példájaként lásd a Budapesti Autonóm Gyülekezet esetét: az új közösség azután jött létre, hogy egy csoport kiszakadt a Hit Gyülekezetéből. 1998 nyarán a Hit Gyülekezete néhány presbitere - saját bevallása szerint - „megelégelte a közösség vezetésében uralkodó állapotokat”, és a felekezet elhagyása mellett döntött. Néhány hónappal később, miután a kivált tagokban megfogalmazódott az igény a közösségi istentisztelet további
} 
portról (vallási közösségről) csak akkor beszélhetünk, ha a minimális fizikai (földrajzi), intézményes (szervezeti) elkülönülés mellett érdemi tanításbeli, rítusbeli, célkitűzésbeli különbségek is érzékelhetőek és a leválás, eltávolodás folyamata és/ vagy az akárcsak külsőségekben megnyilvánuló különbségek kialakulásának folyamata legalább megindult - és néhány fó érdemben elköteleződött a mozgalom, csoport definiált, saját célkitűzéseihez. Tehát nem kizárt, hogy egy új vallási mozgalom (értsd: vallási csoport) egy meglévő vallási közösség keretei között (azaz a tágabb közösség, mint sajátos „ernyőszervezet” égisze alatt) létezzen, de az igen, hogy azonosítható, de legalábbis körülhatárolható tagság nélkül mozgalomnak, illetve önálló, új közösségnek nevezzük. Mindezen konjunktív kritériumok azt is jelentik, hogy például egy új katolikus templom felszentelése, illetve a hozzátartozó plébánia működése általában nem tekinthető új vallási csoport létrejöttének.

A tanításbelinek, illetve gyakorlatinak nevezett különbségek az esetek döntő többségében szétválaszthatatlanul összekapcsolódnak egy-egy csoporton belüli, illetve csoportközi konfliktussal is, a külső szemlélő számára - gyakran ezek definiálatlansága és konstruktív kezelése hiányában - rekonstruálhatatlanná téve az egyes események (előzmények) megtörténtét, sorrendjét és jelentőségét is...

Önálló - belső jellegü, ám nem feltétlenül hazai okokhoz köthető - jelenség egyes új entitások „transzmissziós” típusú megjelenése Magyarországon. Ez csupán annyit jelent, hogy más földrészeken elindult vagy végbement - adott vallási közösséget érintő - változások hazai „begyürűző” hatásaként jelennek meg új denominációk, mennek végbe szakadások, kiválások, ritkábban egyesülések stb. Azaz itt csupán leképezödnek a másutt megindult folyamatok, konfliktusok: gyakran a tanitásbéli különbségek feloldásának eszközeként, vagy éppenséggel a hasonló tanítás mellett egymástól eltávolodó tényleges gyakorlatok miatt. ${ }^{10}$ Magyarországon is megfigyelhető, hogy a '9o-es években rövid ideig létező hagyományos International Church of Christ gyülekezet megjelent, majd elhalt, nem sokkal később pedig az USA-ban abból kivált International Church of Christ (ICOC) kezdte meg misz-

gyakorlására, megalakult az Autonóm Gyülekezet. A Fővárosi Bíróság 1998. november 19-én kelt végzésével hivatalosan is nyilvántartásba vette a 256 természetes személy által alapított egyházat. Ehhez részletesebben lásd Dobszay János: „Szakad a Hit Gyülekezete? Új szövetség.” $H V G, \mathrm{XX}, 1998 / 36,92-99$.

${ }^{10}$ A teológia, illetve az alkalmazott vallástudomány érzékletes példája az 1Tim 4,16-ot („Legyen gondod önmagadra és a tanításra, maradj meg ezek mellett, mert ha így cselekszel, megmented magadat is, hallgatóidat is") használva mutat rá arra, hogy a helyes magatartás (életvitel) egy kétszárnyú repülőgéphez hasonló: amennyiben a helyes tudás (meggyőződés) és az annak megfelelő cselekedet csak együtt érvényesülhetnek, ahogyan a repülőgép is csak mindkét szárnya révén maradhat tartósan a levegőben. 
sziós csapata révén itteni tevékenységét, anélkül azonban, hogy a két hazai gyülekezet tagsága között bármilyen érdemi átfedés lett volna. ${ }^{11}$

A továbbiakban a belső okok kifejtését három - egymást részben át is fedő - fogalom kifejtésével, az általuk nyerhető fogalmi keret kialakításával folytatjuk. E három fogalom a „valláskárosultság”, a „mérgező vallásosság”, illetve a „vallási szélsőség."

\section{VALLÁSKÁROSULTSÁG}

Önállóan kell szót ejtenünk a „valláskárosultakról”: azokról, akik - tipikusan egy-egy régi-új keresztény vagy nem keresztény vallási közösség korábbi tagja(i)ként, az ott megéltek hatására válnak ismét „keresőkké” vagy nemritkán akár a szervezett vallás aktív ellenzőivé. A vallásosságukat a maguk módján megélő, szervezett csoportokhoz nem vagy csak lazán kapcsolódó személyek ilyetén magatartásának hátterében Magyarországon is jelen van egyes esetekben a „vallássérültség”, azaz a korábbi közösségekben szerzett sérülések, rossz tapasztalatok és ezek nyomán kialakult esetleges félelmek, bizonytalanságok és hitbéli problémák miatti távolságtartás. Ezen személyek növekvő száma egyúttal valószínűsíti olyan újabb vallási törekvések megjelenését is, amelyek kifejezetten számukra kínálják fel a "gyógyulás" lehetőségét (a nem kifejezetten ilyen céllal szervezett, de ilyen funkciót is betöltő szervezett képzések között a legismertebbek Beregi László előadásai és sorozatai Budapesten - még akkor is, ha neki nem kimondott, de legalábbis nem elsődleges célja e szerep betöltése...... ${ }^{12}$

A szakirodalomban a valláskárosultság leírására olyan kifejezések (kategóriák) jelennek meg, mint a „mérgező vallásosság” vagy éppen a „vallási szélsőség” kifejezések, melyek egymás mellett - és egymásra tekintettel is - vizsgálva viszonylag pontosan kijelölik e jelenség határait és főbb elemeit. A továbbiakban mindkét fogalmat önállóan is bemutatjuk, tekintve, hogy egymással és a valláskárosultsággal közös metszeteik ellenére előbbi inkább valláspszichológiai, utóbbi pedig inkább vallásszociológiai kategóriaként használható.

${ }^{11} \mathrm{Ma}$ - két névváltoztatást követően - Krisztus Magyarországi Gyülekezete néven vallási egyesület.

${ }^{12} \mathrm{Az}$ általa képviselt, Magyarországon müködő Grace Ministries Alapítvány olyan keresztény felekezetközi szervezet, amely nem kíván saját gyülekezetet létrehozni, munkatársai és a képzéseibe (programjaiba) bekapcsolódók is különböző felekezeti háttérből származnak. Részletesebben lásd: graceministries.hu (2021. 01. 17.) 


\section{MÉRGEZŐ VALLÁsossÁG}

Johannes Hartl (teológus, négygyermekes családapa) az augsburgi Imádság Háza alapítója és vezetője közismert tanulmányában csokorba gyüjtötte a mérgező vallásosság illetve az érzelmileg egészséges spiritualitás jellemzőit. Mint írja, „toxikus jelenség, ha [az adott vallási közösségben] úgy érezzük, soha nem tudunk elég jók lenni, eleget teljesíteni; ha az önképünkben meghatározó a bűntudat; ha az Istenképünket a félelem formálja; ha a saját közösségünkön kívül állókat kevesebbre becsüljük, lenézzük; ha a közösségünkben tilos racionális kérdéseket feltenni, vagy ha a tagok nem kibontakoznak, hanem inkább beszükülnek, szabadságuk csorbul, szomorúbbá, keményebbé válnak. Ezzel szemben az érzelmileg egészséges spiritualitás életörömöt, kreativitást ébreszt; vágyunk az Istennel való kapcsolatra, hiszen Isten számunkra az a szerető Apa, akiről Jézus beszélt, és minden az Ő ajándéka. Ha így élünk, könnyebben teremtünk kapcsolatokat, életünkben helyére és összhangba kerül mind a racionalitás, mind az érzelmek és a spirituális dimenzió. A bűnt, saját kudarcainkat képesek vagyunk beismerni; tudunk bocsánatot kérni és megbocsátani; elviseljük a csalódást, a szenvedést is, és amit nem értünk, azt nem próbáljuk erőnek erejével kimagyarázni. Mindezt erősíti és a mindennapok részévé teszi a rendszeres, de nem túlterhelő lelki élet: imádság, bibliaolvasás, szentségek, böjt." ${ }^{13}$ A mérgező vallásosság problematikája a hazai tudományban is felbukkant már, elsősorban a pszichológia újabb irodalmában. ${ }^{14}$

\section{VALLÁSI SZÉLSŐSÉGEK ${ }^{15}$}

A vallási szélsőségek (extremitások) kérdésköre a hazai - és nemzetközi - szakirodalomban is leginkább az erőszaktól sem visszariadó vallási fanatizmus, ${ }^{16}$ a ter-

${ }^{13}$ Herbert Dóra: „Képek vagy rémképek”. SZEMlélek, 2020. szeptember 5., szombat 19:32, cimlap. blog.hu/\#bloghu/szemlelek/2020/o9/05/kepek_es_remkepek (2021. 01. 17.)

${ }^{14}$ Lásd például Szentmártoni Mihály: „A felnőttkor vallásossága”. Magyar Pszichológiai Szemle, LVIII, 2003/1, 65-81.

${ }^{15}$ A témakörhöz lásd Rixer Ádám: „A vallási szélsőségek tipológiája Magyarországon.” Vallástudományi Szemle, XIV, 2018/5, 15-30. Jelen alpont az ott kifejtettekre épül. A területet vizsgáló, átfogó munkák között lásd például: R. Scott Appleby: The Ambivalence of the Sacred: Religion, Violence, and Reconciliation. Lanham, MD., Rowman \& Littlefield Publishers, 2000.

${ }^{16}$ Sam Cherribi: „Bad Faith: The Danger of Religious Extremism by Neil J. Kressel. Review.” Political Psychology, XXX, 2009/2, 319-323; Laurence R. Iannaccone: „Religious Extremism: Origins and Consequences." Contemporary Jewry, XX, 1999/1, 8-29; valamint Máté-Tóth András: „Kirekesztés: avagy az erőszak vallási legitimációja.” In Szilágyi Tamás (szerk.): Vallás és eröszak: elméleti koncepciók és a globális terrorizmus felemelkedése a 21. században. Szeged, SZTE BTK Vallástudományi Tanszék, 2017, 4-21. 
rorizmus különféle formái, ${ }^{17}$ illetve a „,hagyományos” szekta-kérdés különféle olvasatai formájában van jelen, azzal a szükségszerű megjegyzéssel, hogy az említett jelenségeket megragadni kívánó leírásokban a kereszténység kevésbé érintett. ${ }^{18}$

A legelső kérdés, amit fel kell tennünk, s meg is kell válaszolnunk, hogy mihez képest lesz valami extrém; kinek az álláspontja lesz döntő ebben a kérdésben - nyilván érdemes elkerülnünk a végletesen relativizáló megközelítéseket. ${ }^{19} \mathrm{E}$ kérdésben korábbi tanulmányom kiindulópontjaként rögzítettem, hogy a szélsőséges volt tekintetében elsődlegesen az adott államon - esetünkben Magyarországon - belüli többségi álláspontot ${ }^{20}$ kell meghatározónak tekintenünk, másodlagosan azonban tekintettel az állami szintre emelt vallási szélsőség egyes eseteire (pl. legextrémebben ISIS) - az adott „kultúrkör”, konkrétabban: az adott területen (államcsoporton belül) hagyományosan érvényesülő többségi vagy egyébként elfogadott („bevett”) vallások szokványos jelenségeihez, intézményesült gyakorlataihoz képest beszélhetünk „vallási szélsőségről”. Tehát az adott államon vagy államcsoporton belüli vallási típusú ${ }^{21}$ szélsőségesség(ek) vizsgálata körében növeli az objektivitást, ha egyfajta kontrollfunkcióként - az adott területen (tágabb földrajzi térségben) meghatározó világvallás vagy világvallások uralkodó trendjeivel is egybevetjük ezt a szűkebb, fentebb elsődlegesnek aposztrofált szélsőségesség-felfogást.

Milyen további módszerekkel juthatunk közelebb a „szélsőségesség” megragadásához? Amikor a magyar jogalkotó a vallási tevékenység fogalmát kívánja meghatározni, ad egy pozitív és egy előbbi jelentéstartalmait pontosító, határmeg-

${ }^{17}$ Julia Valerijevna Tuskhova: „ISIS and Al-Qaeda as the Determinants of Religious Extremism in the UK." Society: Politics, Economics, Law. XIV, 2017/8, 1-4; illetve magyarul: Kis-Benedek József: „Vallási szélsőségek a MENA-országokban.” Hadtudomány, XXIX, 2019/1-2, 61-84.

${ }^{18}$ Bővebben lásd még a fentebb említett tanulmány angol nyelvű, bővített változatát: Ádám Rixer: „The Typology of Religious Extremism.” Advances in Social Sciences Research Journal, V, 2018/12, 519-531. A téma korábbi hazai irodalmából: Török Péter: És (a)mikor destruktívak? Az új vallási mozgalmak szociológiája és hazai helyzete. Budapest, SOTE, 2007.

${ }^{19}$ Az egyik csapda e körben az, amikor kijelentjük, hogy minden vallási jelenség szükségképpen „szélsőséges”, tekintve, hogy azok lényege (valamifajta fogalmi magva) mindig az elkülönülés és az „önmérséklet hiánya”. Ez a fajta relativizálás, illetve abszolutizáló törekvés nyilván figyelembe veendő, ám még ezen álláspont részleges elfogadása sem teszi szükségtelenné a jelenségek valamilyen tudatos rendszerezését. Charles S. Liebman: „Extremism as a Religious Norm.” Journal for the Scientific Study of Religion, XXII, 1983/1, 75-86.

${ }^{20}$ Többségi álláspont alatt - demokratikus alapszerkezetű társadalmat feltételezve - a nyilvánosság szféráiban artikulált politikai, szakmai, szükebben vett tudományos és a médiumok által megjelenített egyéb álláspontok valamifajta súlyponti, jellemző véleményét, általánosnak nevezhető megközelítésmódjait értjük.

${ }^{21}$ A vallás hagyományos fogalmát e kutatás nem érinti, továbbra is elfogadjuk, hogy a vallás nem más, mint egy értékelhető fokban intézményesült, szervezett és a jog által (is) megragadható, sajátos hitéleti objektiváció. 
vonásokat alkalmazó negatív definíciót. ${ }^{22}$ Álláspontunk szerint a vallási tevékenység fogalmához hasonlóan a vallási szélsőség fogalma tekintetében is lehetséges egy negatív, illetve egy pozitív meghatározás is: a negatív definíció azt mutatja meg, hogy melyek azok a jelenségek, amelyek bár a vallással, sőt intézményes vallással is érintkezhetnek, összekapcsolódód(hat)nak, de mégsem tekinthetőek vallási eredetű vagy vallási természetű „szélsőségnek”; a pozitív definíció pedig egy taxatív lista keretében tesz kísérletet a szélsőségek lehetséges, főbb (hazai vagy általánosabb) típusainak felsorolására.

A vallási szélsőség negatív definíciója körébe kell sorolnunk például azokat a jogsértéseket, amelyek nem az adott vallás tanításaiból következnek, hanem - adott esetben - a nyilvántartásba vételi eljárás során egy csatolni elmulasztott melléklet formájában megjelenő emberi mulasztást feltételeznek. Ugyanígy, nem minősülhet vallási szélsőségnek pl. egy vallási rendezvényen bekövetkező lopás, amennyiben ez általában nem tekinthető az adott közösség „lényegéből” következő, általánosítható jelenségnek. Szintén problematikus az, amikor egy adott gyülekezet vagy egy több helyi gyülekezetből álló nagyobb vallási közösség vezetőinek kisebb-nagyobb gyengeségeiből következtetünk a müködés vagy tanítás általánosan szélsőséges voltára, azaz önmagában egy „rossz,” „bünös” vezető vagy hibás vezetési gyakorlat sem eredményezhet önmagában „vallási szélsőséget”. E körben hangsúlyoznunk kell azt is, hogy önmagában az a tény, hogy egy vallási alapú, a

${ }^{22}$ A lelkiismereti és vallásszabadság jogáról, valamint az egyházak, vallásfelekezetek és vallási közösségek jogállásáról szóló 2011. évi CLXXV. törvény (a továbbiakban Ehtv.) a 6. \$-ában a következőképpen fogalmaz: „(3) A vallási tevékenység olyan világnézethez kapcsolódó tevékenység, amely természetfelettire irányul, rendszerbe foglalt hitelvekkel rendelkezik, tanai a valóság egészére irányulnak, valamint sajátos magatartáskövetelményekkel az emberi személyiség egészét átfogja." A (4) bekezdés értelmében „Önmagában nem tekinthető vallási tevékenységnek a) a politikai és érdekérvényesítő, $b$ ) a pszichikai vagy parapszichikai, $c$ ) a gyógyászati, $d$ ) a gazdasági-vállalkozási, $e$ ) a nevelési, $f$ ) az oktatási, $g$ ) a felsőoktatási, $h$ ) az egészségügyi, $i$ ) a karitatív, j) a család-, gyermek- és ifúságvédelmi, $k$ ) a kulturális, $l$ ) a sport, $m$ ) az állat-, környezet- és természetvédelmi, $n$ ) a hitéleti tevékenységhez szükségesen túlmenő adatkezelési, valamint $o$ ) a szociális tevékenység”. A leírtak egyúttal azt is jelentik, hogy egyes „mozgalmak”, szervezett, spirituális jellegü törekvések sem a pozitív, sem pedig a negatív definíció alapján nem lesznek vallási közösségnek, csoportnak stb. tekinthetőek. - Így például a szcientológia, a Transzcendentális Meditáció (TM), a Silva-féle Agykontroll nem felelnek meg a vallás fogalmának, amennyiben tevékenységük középpontjában az egyén, illetve a szervezet boldogsága, fejlődése, sikere áll. Ezen mozgalmak egy részére az is igaz, hogy kapcsolódás (kapcsolat) a szervezet képviselöje és a tag között áll fenn, az egyes tagok között nem, vagy csupán reziduális jelleggel. Természetesen hasonló tendenciák lehetnek (új) keresztény jellegü, irányultságú mozgalmakban is: pl. a szakirodalomban is jól dokumentált „sikerteológia” nyomán, ahol az egyes tagok közötti kapcsolat nem intenzív, a gyülekezeti alkalmak, dicsőítések, közös egzaltációk jelentik a közösség megélésének döntő színterét, a „jóléti evangélium” hirdetésének és befogadásának döntő platformját. Utóbbihoz lásd még Havasi: „Vallási körkép”, 3. 
társadalom által tudomásul vett, de a többség által nem követett szük csoportnorma logikailag összekapcsolható konkrét jogsértésekkel (pl. a cölibátus intézménye a cölibátusban élö személyek által gyermekek sérelmére elkövetett szexuális büncselekményekkel) nem feltétlenül eredményezi azt, hogy magát a vallási közösséget is „szélsőségesnek” tekintjük, különösen, ha - amint azt a felhozott példa is mutatja - a csoportnorma nem a vallási nézetrendszer „lényegéhez” tartozó elem, illetve az adott vallási közösség is érdemben fellép az adott intézmény káros implikációival, illetve a konkrét bántalmazó jelenséggel szemben. ${ }^{23}$ Természetesen az „elszigeteltebb” jelenségek is eredményezhetik - ahogyan eredményezik is - a közösség elhagyását, a kiválást, s közvetve akár új csoportok létrejöttét is.

A pozitív definíció tekintetében - a fentiekből is következően - érdemes rögzítenünk, hogy szélsőségesnek leginkább a kiterjedt, általánositható gyakorlatokat, jelenségeket tekinthetjük; az elszigetelt, sporadikus, egy-egy személyhez köthetö, az adott vallás (valláson belüli vallási irányzat) tanításaiból le nem vezethető gyakorlatokat általában nem érdemes ebbe a körbe sorolnunk. A szélsőséges jelenségek csoportosítását, sőt, tipizálását megkönnyítő - s korábbi munkámban részleteiben is kifejtett - szempont lehet:

a) a szélsőség révén sérülő, a többségi társadalom által elfogadott, vallott norma típusa (hogy tudniillik jogi vagy egyéb társadalmi normatípus sérelméről van-e szó);

b) hogy az adott vallási közegen, közösségen kívülre hat-e „szélsőséges” magatartás, vagy éppenséggel - döntően - azon belül maradva fejti ki káros hatását, illetve

c) hogy az eröszakos jellegü-e.

${ }^{23}$ A katolikus (világ)egyházban több hullámban zajlott, zajlik a szembesülés, illetve szembenézés ezzel a jelenséggel is. 2012. február 6. és 9. között nemzetközi tanácskozást tartottak Rómában a világ különböző egyházmegyéiből érkezett püspökök és szerzetesrendi elöljárók részvételével az egyház hivatalos képviselői által elkövetett szexuális gyermekbántalmazások elleni fellépésről és az áldozatok megsegítéséről. Erre nézve lásd: Sz. N.: „Bátor szembenézés: Hatékony fellépés a gyermekek szexuális kihasználóival szemben.” Korunk, XXIII, 2012/4, 99-106. Az egyes országok (tagegyházainak) gyakorlatára nézve lásd továbbá Jo Renee Formicola: „Recalibrating U.S. Catholic Church-State Relations: The Effects of Clerical Sexual Abuse." Journal of Church \& State, LVIII, 2016/2, 307-330; illetve Kathleen McPhillips: „The Church, the Commission and the Truth: Inside the NSW Special Inquiry into Child Sexual Abuse." Journal for the Academic Study of Religion, XXIX, 2016/1, 30-51. Ezen írások kiindulópontja - szinte minden esetben az, hogy az ügyek eltussolásában az egyházi elöljárók mellett évtizedekig az állami hatóságok is érdemben közreműködtek. 
A fenti kiindulópontok (szempontok) alapján bizonyosan lehetséges az endogén okok egy részének pontosabb megragadása, leírása. Megjegyezzük, hogy az említett okok (okcsoportok) tömegességét, jelenlétének intenzitását mindig befolyásolja, hogy az adott államalakulat (esetünkben Magyarország) milyen irányban, mértékben és milyen módon elfogult egyik vagy másik vallás tekintetében, azaz, hogy az adott állam vallási politikája mennyiben tekinthető támogatónak vagy akadályozó jellegünek valamely egyébként „szélsőségesnek” tekinthető vallási jelenség vagy jelenségcsoport tekintetében. Mindazonáltal az állam szerepe ebben a vonatkozásban általában csupán közvetett, így részletesebb elemzésre csak azon további pontok tekintetében kerül sor, ahol is az államnak közvetlen és meghatározó szerepe van az új vallási csoportok létrejöttében.

\section{II.2. A MÁSODIK OKCSOPORT: ÚJ - KÖZVETLEN INTÉZMÉNYES ELŐZMÉNYEK NÉLKÜLI - KÖZÖSSÉG, ILLETVE MOZGALOM LÉTREJÖTTÉNEK NEM KÖZVETLEN ÁLLAMI FELLÉPÉSBÖL KÖVETKEZŐ OKAI}

Amikor azt a kérdést fogalmazzuk meg, hogy miért hoznak létre új vallási csoportokat az emberek, a legkézenfekvőbb válasz az, hogy a meglévő struktúrákkal, gyakorlatokkal, tanításokkal stb. kapcsolatos elégedetlenség, illetve ezen belső viszonyok reformálhatatlanságának érzete az, ami miatt a legtöbbször bekövetkezik a „váltáa”, az „új kezdet”. Ezek vázlatos bemutatását el is végeztük az előző fejezetben, azt állítjuk azonban, hogy ezek mellett léteznek/létezhetnek olyan közösségalapitó, illetve mozgalmi törekvések is, amelyek organikus formában, önfejlödéssel, egyértelmüen meghatározható intézményes elözmények nélkül, tipikusan kisebb, valamilyen szempontból eleve (el)zárt közösségekben alakulnak ki - anélkül, hogy a leendö tagoknak érdemi (vagy egymáséval azonos, egymáséhoz hasonló) vallási előéletük volna. Fogalmilag tehát nem kizárt, hogy egy vallási csoportosulás (közösség) úgy jöjjön létre, hogy egyetlen tagjának (szervezőjének, kezdeményezőjének) sincs vallási előélete, érdemi előismerete vagy korábbi szervezeti tagsága - még akkor sem, ha az újonnan létrejövő entitások többségében nem ez a helyzet... Jelen pontban megelégszünk azzal, hogy a közvetlen előzmények nélküli vallási csoportokat vizsgáljuk: ezeket - az egyszerüség kedvéért, a civil szervezetek kapcsán bevett kifejezést kölcsön véve - nevezzük vallási grassroots mozgalmaknak ${ }^{24}$ (csoportok-

\footnotetext{
${ }^{24}$ A politikatudományban bevett kifejezés a civil társadalom alulról szerveződő, lazán strukturált képződményeit, mozgalmait tekinti e körbe tartozónak. A fogalom egyik legismertebb megközelítéseként lásd: R. Melucci: „Social Movements and the Democratization of the Everyday Life." In John Keane (szerk.): Civil Society and the State. London - New York, Verso, 1988. Saját
} 
nak). A mögöttes okok - egy-egy ilyen entitás szárba szökkenése mögött - számosak és egymással is jól megférőek. Nyilván a társadalmi, kollektív és egyéni okok végtelen sora hozható fel, a társadalomtudomány (s azon belül a vallástudomány) azonban kirajzol néhány kitüntetett okot.

Így, az alapítók és az újonnan csatlakozók esetében is igen jelentős hajtóerő a fogyasztói társadalom normái és gyakorlatai, illetve az elmagányosodás hatásai ellenében érvényesített egyéni, illetve közösségi helykeresés - mint közvetlen, mögöttes, nem vallással összefüggő eredeti ok.

\section{II.2.1. A KÖZÖSSÉG-IGÉNY}

Természetesen az emberi létnek vannak bizonyos, sok-sok évtizedet átfogó és az ezen idő alatt kialakult, fennállt korszellemet átfogó, visszatükröző tipikus nehézségei. Bizonyosan ilyen a hagyományos közösségek leépülése, a családi és egyéb struktúrák töredezetté válása a modern társadalmakban.

Havasi - miután felteszi a kérdést, hogy miért jönnek létre új vallási mozgalmak -, a legfontosabb, szakirodalmi okok között a kiábrándultságot, a mai világtól, fogyasztói szemlélettől való elfordulás vágyát, az identitáskeresést, az erkölcsi elbizonytalanodást, $s$ végezetül a közösség iránti vágyat hozza fel lehetséges válaszként. ${ }^{25}$ Máté-Tóth András és Nagy Gábor Dániel a nagyobb egyházaktól való elfordulás KSH-adatokkal alátámasztott okaként tanulmányukban arra jutnak, hogy „[...] a társadalom modernizációja és a vallás és kultúra privatizációja [nyomán] [a] magyar társadalom évtizedek óta küzd a közösség-hiány problematikájával, ami a nagy társadalmi intézményekkel szembeni távolságtartásban is megnyilatkozik. A friss népszámlálási adatok üzenete az, hogy olyan szellemiség és politika szükséges Magyarország számára, amelyben a közösségépítés és a szolidaritás kiemelt prioritásként van jelen." ${ }^{26}$

vallási grassroots fogalmunk hangsúlyozza (kiemeli) a közvetlen intézményi előzmények hiányát is.

${ }^{25}$ Havasi Virág: „Keresztény új vallási és vallási megújulási mozgalmak Magyarországon 1945-től napjainkig." Egyháztörténeti Szemle, XIX, 2018/4, 106-119, ezen belül 107.

${ }^{26}$ Máté-Tóth András - Nagy Gábor Dániel: „A 2011-es Népszámlálás vallási adatairól” Egyház és Társadalom, 2013. 04. 04. egyhazestarsadalom.hu/2013/04/04/mate-toth-andras-nagy-gabor-daniel-a-2011-es-nepszamlalas-vallasi-adatairol (2021. 01. 17.) A tanulmányban - a KSH adataira támaszkodva - kifejtésre kerül, hogy 2001-ben a teljes népesség 54,5\%-a vallotta magát katolikusnak, 2011-ben a 39\%-a (számszerűen a vizsgált időszakban a római katolikusok száma mintegy 1600 ooo-rel csökkent, a görögkatolikusoké mintegy 90 ooo-rel). Református: 15,9ről 11,6-re csökkent (számszerüen közel 470 ooo fővel csökkent). Evangélikus 3-ról 2,2 (90 ooo fö). A külön is nevesített vallások között az izraeliták között volt - arányaiban - a legkisebb 
Természetesen a közösség-igény nem csupán elvezet(het)i az egyént a vallásig, egy adott vallási csoportig, de a vallási csoport lényeges sajátosságaként, sőt a vallási csoport humán közszolgáltatásait „külső haszonélvezőként” igénybe vevők számára is meghatározó, folyamatosan újratermelődő mozzanatként a vallási szféra egészének jellegadó vonása. A vallás mint közösségformáló tényező felsorolhatatlanul sokféle módon képes szolgálni az adott vallás gyakorlói mellett a szélesebb társadalmi környezet szereplőit is: a „társadalmi jóllét” szolgálata megelőző, gyógyító és felkészítő funkciók ellátása révén valósul meg a vallási csoportokon belül és azokon kívülre irányuló formákban. ${ }^{27}$

A társadalomtudományok számára már jó ideje evidencia, hogy a mentális egészség és a közösséghez tartozás között milyen szoros összefüggés van, ${ }^{28}$ de a vallási praxis, a gyakorló lelkészek is visszaigazolják ezt - s nem csupán az új közösségek létrejöttének okaként, hanem a hagyományos vallási entitásoktól való elfordulás egyik tényezőjeként is. Hortobágyi Zoltán kérdésére - „Mostanában különösen érezhetö, hogy az emberek elfordulnak az egyházaktól. Nem okoz-e ez szorongást a papságban?” - Gyökössy Endre a vele készült interjúban a következő választ adja: „Nyilván igen. De nem Istentől fordulnak el. Hallatlan spirituális szomjúságot érzek azoknak a beszédében, lényében, akik engem fölkeresnek, meg egyébként is. Itt a történelmi egyházaktól fordulnak el az emberek, az institúciótól, a merevségtól, a dogmáktól, de a hittól nem. Hallatlan szomjúságot, hitbeli szomjú-

a visszaesés. A „más egyházhoz, felekezethez tartozók” száma 70\%-kal nőtt (o,9-ről, 1,7-re), továbbá Az „egyházhoz, felekezethez nem tartozók” aránya is a korábbi 14,5\%-ról, 16,7\%-ra nőtt ugyanebben az időszakban. Tehát a nagyobb, hagyományos egyházaktól való elfordulás látványos. Az egyéb kutatások, felmérések is csökkenést mutatnak, tehát a trend egyértelmű, még akkor is, ha a képet árnyalja, hogy a 2001-ről 2011-re 10,8-ról 27,2-re nőtt a nem válaszolók aránya is (ami közel 1700 ooo fö). Lényeges, hogy a vallási kérdésre nem válaszolók aránya másutt is nő. A legújabb felmérések is hasonló irányokat mutatnak: Kovács Benedek - Lajtai Mátyás: „Magyarország vallási viszonyai a népszámlálások és egyéb lakossági adatfelvételek tükrében”. Statisztikai Szemle, XCVIII, 2020/6, 573-598.

${ }^{27}$ Maton, Kenneth I. - Wells, Elizabeth A.: „Religion as a Community Resource for Well-Being: Prevention, Healing, and Empowerment Pathways." Journal of Social Issues, LI, 1995/2, 177-193.

${ }^{28}$ Van Uchelen, Collin: „Individualism, Collectivism, and Community Psychology.” In Julian Rappaport - Edward Seidman (szerk.): Handbook of Community Psychology. New York, Springer Science, 2000, 65-78. A hazai szakirodalom a vallásosság pozitív, személyes elkötelezettségen alapuló formáit egyenesen a mentális egészség védőfaktoraiként tartja számon. Pl. Ferenczi Andrea: „Megmérni a mérhetetlent - a sémák és az istenkép összefüggései.” In Furkó Péter - Szathmári Éva (szerk.): Népszerü tudomány, tudománynépszerüsités, Studia Caroliensia. Budapest, KRE - L’Harmattan, 2019, 81-89: 81. Lásd továbbá: Kopp Mária - Székely András - Skrabski Árpád: „Vallásosság és egészség az átalakuló társadalomban.” Mentálhigiéné és Pszichoszomatika, V, 2004/2, 103-125; illetve Martos Tamás - Kézdy Anikó: „Vallásosság, lelki egészség, boldogság." In Horváth-Szabó Katalin (szerk.): Vallásosság és személyiség. Piliscsaba, PPKE, 2007, 51-83. 
ságot érzek. És talán ez okozza, hogy Magyarországon, úgy tudom, ötven és hatvan közötti ún. miniegyház van bejegyezve, amelyek tulajdonképpen azt kísérlik meg pótolni, amit a történelmi egyházak elfelejtettek, például a közösséget. ${ }^{29}$ Nálunk a nagy templomok közönsége olyan, mint egy operai vagy színházi közönség, ahol nem illik a szomszédot megszólítani. Ez képtelenség volt az ősegyházban, ott együtt voltak, egy nagy család. Ezekben a kis közösségekben összeülnek és együtt imádkoznak, együtt könyörögnek, mondhatnám, hogy elölről kezdik a keresztyénséget. [...] Túlságosan instituálódtunk, túlságosan rutinná váltunk, és azt gondoljuk, hogy egy mise, vagy egy istentisztelet ámenje után vége van az istentiszteletnek. Dehogy! Én az ifjú papi generációnak nem tudom eléggé nyüszíteni, sikítani, kiabálni, hogy ezt tegyétek: tegyétek személyessé a kapcsolatot a híveitekkel”.30

A szekularizációs folyamatok kiteljesedésével a vallás elhalványul, s racionális oksági (világ)magyarázatok kerülnek előtérbe: a vallás magánéleti jelenséggé válik. ${ }^{31} \mathrm{~A}$ társadalmi színterek és az egyéni lét funkcionális differenciálódásával a szükségletek kielégítésének létrejönnek és rögzülnek az új színterei, amelyek versenyeznek a vallás által felkínált üdvjavakkal (és „élményjavakkal”) és egyre inkább autonómmá válnak - elegendő Max Weber vagy a későbbi szerzők közül Georg Simmel megközelítéseire gondolnunk. Mindez azonban egyúttal ciklikus folyamat is: a „halványulás” időről időre ellenhatást és „vallási újjáéledést”, deszekularizációs hatásokat ${ }^{32}$ generál. Sőt, Magyarországon azt tapasztaljuk, hogy „természetjog-ellenes erkölcsi relativizmusra”, ${ }^{33}$ a "posztmodern nihilizmusra” ${ }^{34}$ adott válaszként nem csupán az egyéni és csoportos törekvések, de a közpolitika és közjog szintjére emelt állami akaratnyilvánítások is új - relacionalista, közösségelvü és a különféle hagyományokat elötérbe állitó - közmegegyezések kimunkálását, végső soron a közjó új alapokra helyezését és egy újraértelmezett identitás megformálását igénylik - ennek részeként kezelve a vallási szempontok és tradíciók körét is.

${ }^{29}$ Kiemelés a jelen cikk szerzőjétől.

${ }^{30}$ Hortobágyi Zoltán: „Papság, neurózis, vallási közösség. Beszélgetés Gyökössy Endre teológussal." Magyar Szemle, IV, 1995/8, 839-842, ezen belül 841.

${ }^{31}$ Havasi: „Vallási körkép”, 16.

${ }^{32}$ Peter Berger: „The Desecularization of the World: A Global Overview." In uő (szerk.): The Desecularization of the World: Resurgent Religion and World Politics. Grand Rapids, William B. Eerdmans Publishing Company, 1999, 1-18; továbbá a hazai szakirodalomban: Rosta Gergely: „Szekularizáció? Deszekularizáció? Merre tart a vallási változás a világban?” Magyar Tudomány, CLXXX, 2019/6, 792-803.

${ }^{33}$ Francis Fukuyama: A történelem vége és az utolsó ember. Ford. Somogyi Pál László. Budapest, Európa, 1994, 471.

${ }^{34}$ Frivaldszky János: Jó kormányzás és a közjó politikai és jogfilozófiai szemszögböl. Budapest, Pázmány Press, 2016, 77. 
Az elidegenedés (bizonyos értelemben elvilágiasodás) jelenségei, mechanizmusai tehát a vallási szférát sem kímélik: a kereszténység racionalizálódásával, az Isten-ember kapcsolat közvetlenségének, személyességének háttérbe szorulásával egyfajta varázstalanodás is zajlik - erőteljes ellenhatásokat is eredményező módon. Ennek - mármint az elidegenedésnek - egyik mellékhajtása lehet a vallási pluralizmus is, amely maga is erősít(het)i a szekularizációt: a tartós és intenzív együttélés ugyanis véleménnyé - hosszabb távon pedig „kulturális színfolttá” silányít(hat)ja a vallási meggyőződést. Amellett ugyanis, hogy az ökumenizmus párbeszédre, nyitottságra, beszélgetésre, a közös dolgok elötérbe helyezésére, megértésre törekvő célkitűzéseihez hozzárendelhetőek bibliai elvek és szabályok is, ${ }^{35}$ az ökumenizmus a helyes dolgokat (szeretet a kapcsolatokban, párbeszédre nyitottság, a másik érdekeinek szem elött tartása) és - a teológiai nézőpontból - helyteleneket (szinkretizmus) is erösítheti. ${ }^{36}$

\section{II.2.2. A VALLÁs MINT A PILlANAT SZÜLTE KÉRDÉSEKRE ADOTT VÁLASZ}

Ezen „stabil” és jól kitapintható problémahalmaz (közösség iránti igény) mellett rövidebb időszakonként adódnak kortárs kérdések is, melyekre - éppen határhelyzeti jellegük miatt - hihető és a Biblia kijelentéseivel érdemben összekapcsolt válaszokat kell adnia egy (új) keresztény mozgalomnak (is). Ilyen például napjainkban a járványok kezelésének kérdése és általában a betegségeknek, illetve a szenvedésnek az ember életében játszott szerepe... ${ }^{37}$ Amennyiben a stabil, régóta jelen lévő és az egészen új külső hatások találkoznak, és egyenesen egymást erő-

${ }^{35}$ Lásd például: „Békességre törekedjetek mindenkivel és megszentelődésre, mert enélkül senki sem fogja meglátni Istent" (Zsid 12,14).

${ }^{36}$ Eme izgalmas kérdéshez lásd például: Prancz Zoltán: „Elvhűség és vallási türelem: Össze kell-e békíteni eszmeileg a vallásokat ahhoz, hogy követőik békében éljenek egymással?” Sola Scriptura, XXI, 2019/2, 17-20; illetve Szabó Ferenc: „Keresztény hitünk a vallási pluralizmus korában." Egyházfórum, XXXIII, 2018/2, 1-14.

${ }^{37}$ Közvetett célja pedig annak bemutatása, hogy hol is helyezhetőek el Isten nagy tervében a testi szenvedések, általánosságban a különféle nehézségek? Olyan kérdések merülnek fel ebben a tágabb kontextusban, minthogy „Lehet-e bármi értelme egy betegségnek?”, „Ki okozza a szenvedést?”, „Minden nehézség mögött Sátán áll?”, „Milyen kapcsolatban áll a szenvedés, a betegség a bünnel?”, „Milyen értelmes, a Bibliában is fellelhető, és szeretetből fakadó oka lehet annak, hogy Isten megengedi, hogy beteggé váljunk?”, „Hogyan kapcsolódnak össze a betegségek, járványok és a különféle ószövetségi áldozatok?”, „Minek az előképe az Ószövetség mindahány testi és lelki tisztasággal kapcsolatos elöírása, mi felé mutatnak ezek a rendelkezések?”. Részletesebben lásd Rixer Ádám: „A normativitás kezdetei. A járványok szerepe és kezelése az Ószövetségben." Létünk (megjelenés elött). 
sítő mechanizmusokká állnak össze, ezek még együttesen sem feltétlenül hoznak létre új vallási mozgalmakat, de fogalmilag nem kizárt, hogy például egy társadalmi-gazdasági-egészségügyi kataklizma középtávon vallási típusú, és a teológiai válaszok mellett szervezeti önállósodásban is testet öltő változásokat, azaz csoportokat, mozgalmi jellegủ folyamatokat is generáljon. Például a COVID-19 koronavírus járvány 2020 tavaszán olyan világméretű járvánnyá fejlődött, amelynek eme tanulmány írásakor még nem is látjuk a végét: a korlátozások feloldása, az „élet teljeskörü újraindulása" még várat magára. Ez az időszak különösen élesen veti fel azokat a kérdéseket, amelyek a fejlett világ társadalmaiban a jogok és materiális javak folyamatos bővülése és a vallástalanság stabilizálódása mellett a tematizált közbeszédnek csupán megtürt, 'kulturális érdekességgé' redukált tárgyaiként vannak jelen: Mi az alapvetö, elsödleges oka a létezésemnek? Miért történik velem mindaz, amin eddig átmentem, s az, amivel majd csak ezután kell szembenéznem? Ki vagyok én? Mivel tartozom a szükebb és tágabb közösségemnek? Mit jelent jól szeretni magamat, a másik embert és Istent? Van-e sorrendisége ezen kapcsolatoknak? Mivel tartozom a tárgyi környezetemnek, az engem körülvevő természetnek? Miért? Van-e választásom mindezekkel kapcsolatosan?

Azt érzékeljük, hogy - maradva a koronavírus-járvány példájánál - a karantén-, illetve távolságtartási szabályok egyrészt tovább erősítik az elmagányosodási és más hasonló tendenciákat, másrészt azonban a helyzet egésze erősíti a társadalmi szolidaritás meglévő és újonnan körvonalazódó struktúráit, intézményeit. S ezek elemzése nélkül is belátható, hogy e kettős, párhuzamosan jelenlévő hatás keltette „feszültség” befolyásolja a társadalom valamennyi alrendszerét, azaz a vallási alrendszer működését, minőségét és átalakulását is.

\section{II.2.3. A VISSZAÉLÉSEK ESETE}

Az új vallási csoportok létrejöttének hátterében azonban nem csupán tisztességes törekvések húzód(hat)nak meg, hanem visszaélésszerű okok és magatartások is. Önálló csoportban kell foglalkoznunk azokkal az esetekkel, amikor is a mozgalom vagy egyéb entitás alapításának hátterében tisztességtelen - azaz a jog és közmorál mércéje szerint is elítélendő - motivációk, tipikusan anyagi haszonszerzési szándékok húzódnak meg. Ezek döntően olyan esetek, amikor a szervezet eleve visszaélésszerüen (pontosabban visszaélés céljával, de politika-független okból) jön létre a jog által lehetővé tett formában, adómentesség, adóminimalizálás, támogatás-szerzés stb. céljából (tehát elsődlegesen gazdasági okokból). Ilyenkor az új vallási entitás - egy értékalapú vizsgálat alapján - nem is feltétlenül tekinthető vallásinak...

A vallási közösségekkel kapcsolatos jogalkotás leggyakrabban akkor kerül reflektorfénybe, amikor egyes szélsőséges(nek látszó) vallási gyakorlatokra reagálva 
az erre jogosult elszánja magát a változtatásra. ${ }^{38}$ Magyarországon a rendszerváltozást követöen több hullámban is felmerültek problémák, visszaéléses gyakorlatok; így például a kegytárgyakkal kapcsolatos mentességek nyomán;39 a külföldről érkező egyházi szolgálattevőkre irányadó enyhébb letelepedési szabályokkal, illetve könnyített vízum-ügyintézéssel összefüggésben; a „perselypénz” adómentességével kapcsolatban és a sorkatonai szolgálat kikerülését célzó egyházalapításokkal összefüggésben is - egyebek mellett. Ám ezekkel a jelenségekkel kapcsolatban elmondható, hogy a hatóságok nem vagy csak a legkirivóbb esetekben léptek fel, így például az elhíresült a Gyurcsok József-féle ügyben, ${ }^{40}$ amelyben az ügyészség vállalta a nyílt fellépést is.

Amint azt a következő fejezetben látni fogjuk, az állam az egyedi és nyílt konfrontáció helyett - azaz egyedi hatósági döntések helyett - az esetek döntő többségében a jogalkotás (törvényi szintű új szabályozás) formáját választotta, a generális szabályozással próbálva elejét venni a további visszaélésszerü gyakorlatoknak (is).

\section{II.3. A HARMADIK OKCSOPORT: ÁLLAMI FELLÉPÉS AZ ÚJ VALLÁSI CSOPORTOK (KÖZÖSSÉGEK) MEGJELENÉSÉNEK HÁTTERÉBEN. MEGLÉVÖ SZERVEZETEKRE HATÓ KÜLSÖ (EXOGÉN) ÉRDEMI OKOK}

Meglévő szervezetre ható külső (exogén) érdemi okok között kiemelkedő szerepük van az állami jogalkotás révén megjelenő külső kényszereknek [átalakulás, megszünés, újjáalakulás más jogi formában, s ezekhez kapcsolódóan a szervezeti felépítés, tevékenység módosítása, tagsági (jog)viszonyok rendezése egy új, ön-

${ }^{38}$ Krystyna Daniel - W. Cole Durham: „A vallási azonosságtudat mint a nemzeti identitás összetevője." Fundamentum, I, 1997/2, 3-14, ezen belül 6.

${ }^{39}$ A hitélethez szükséges kiadvány, kegytárgy előállítása, értékesítése nem minősül gazdasági-vállalkozási tevékenységnek, aminek a jelentősége abban áll, hogy az adott egyház ezáltal ezen tevékenység vonatkozásában mentesül adó- és járulékfizetési kötelezettségei alól. Korábban egy alkalommal történt kísérlet arra, hogy nem vallási természetü tárgyakat új egyház alapításával kegytárgyként forgalmazzanak: így például figyelmet érdemel a Győrújbaráti Motoros Egyesület kísérlete, amely egy motoros cikkeket árusító bolt köré szervezett volna egyházat, abból a célból, hogy a boltban kapható tárgyak mindegyike kegytárgynak minősülhessen, s így komoly anyagi előny realizálódhatna/realizálódhatott volna. A kegytárgyként - vámmentesen - behozott árukat aztán - szintén kegytárgyként - adómentesen értékesítették volna. Honlapjukon sokáig olvasható volt: „[...] egyesületünk tagjai minden évben hálát adnak a Szent Karburátor Istenének és gyermekének a Szent Injektornak.” Rixer Ádám: „A vallás fogalmáról.” Jogelméleti Szemle, XIV, 2011/4, 1-8, ezen belül 5 .

${ }^{40}$ A nevezett személy által folytatott távgyógyítás nem szerepelt az egyház (Egyetemes Szeretet Egyháza) alapító okiratában - ez volt a Pest Megyei Bíróság előtti eljárás tárgya. 
képében is változó vallási entitást hoz létre], s miközben az esetek többségében csupán látszólagos változásról van szó, az állami befolyásolás közvetve és közvetlenül is eredményezhet mélyreható, érdemi változásokat is, amelyek végső soron a szervezet jellegét, tevékenységét, a szervezet által ellátott, felvállalt külső-belső feladatok jellegét és mértékét is befolyásolhatják... ${ }^{41} \mathrm{~A}$ 2011-12-ben megindult, a vallási szféra szereplőinek körét, elnevezését, adórendszeren keresztüli támogatásának szabályait átrajzoló „reform” hatása igen jelentős volt Magyarországon, komoly nemzetközi visszhangot is kiváltva. ${ }^{42}$

Ehelyütt a lelkiismereti és vallásszabadság általános - akár európai, ${ }^{43}$ akár hazai - helyzetére részleteiben nem kitérve, rögzítsük, hogy az új Ehtv. nyomán a korábbi mintegy 230 egyház helyett 2017 év végén 32 bevett egyház volt Magyarországon, ez azonban nem a szféra belső önmozgásának köszönhető, hanem a radikális állami beavatkozásnak, amely a korábban létezett szervezetek döntö többségét a számos adózási és egyéb előnyt jórészt nélkülöző egyesületi formába kényszerítette. A jogalkotói magyarázat éppen a visszaélésekkel szembeni fellépés szándéka volt, de - nem elemezve e szándékokat - tényszerüen megállapítható, hogy a beavatkozás rendkívüli mélységü és terjedelmű volt. Azaz - s szűkebb témánk szempontjából ez a lényeges - az új (elnevezésében, szervezetében is részben átalakuló) entitások létrejöttének egyik lényeges okát azonosíthatjuk eme állami beavatkozásban. Bizonyos mértékig egy ingahatásról van szó: a teljesen formális jellegü bejegyzési (nyilvántartásba vételi) eljárást a közvetlen állami kényszer váltotta fel. A 2012 előtti bő húsz évben ugyanis az egyházak nyilvántartásba vételi eljárása teljesen formális volt, leginkább azért, mert a bíróságok a kérelmezők nyilatkozatainak megtörténtén, illetve az általuk kötelezően benyújtandó dokumentumok létén túl nem végeztek érdemi vizsgálatokat: sem a dokumentumok tartalmának - azaz tényállításainak - valódisága, sem pedig a szervezetek létrejöttének tényleges okai és céljai tekintetében. ${ }^{44} \mathrm{Azaz}$, amennyiben a megfelelő alakszerüséggel benyújtott

${ }^{41}$ Az állami fellépés elvileg kiválthatja korábban még semmilyen formában nem létezett (előzmények nélküli) vallási entitások létrejöttét is, ám ezzel a kérdéssel - annak gyakorlati jelentősége híján - jelen tanulmányban nem foglalkozunk.

${ }^{42}$ Baer H. David: „Lasst sie uns nach unserem Bilde machen! Wie durch Ungarns Religionsgesetz die religiöse Landschaft umgestaltet werden soll." In Kai Funkschmidt (szerk.): Mit welchem Recht? Europäisches Religionsrecht im Umgang mit neuen religiösen Bewegungen. Berlin, EZW-Texte 234, 2014, 161-178. A témához lásd még Rixer Ádám: „Állam, jog és törvény. Régi szereplők új szerepekben.” In Erdélyi László (szerk.): Egyházügyi, vallásszabadsági tudományos konferencia: Budapest, 2011. november 21. Budapest, Boldog Élet Alapítvány, 2011, 33-51.

${ }^{43}$ Ehhez lásd: Uitz Renáta: „Lelkiismereti és vallásszabadság a multikulturális Európában. Hogyan tovább? Hova tovább?” Jogtudományi Közlöny, LXXIV, 2019/5, 213-228, ezen belül 223.

${ }^{44}$ A szférát szabályozó korábbi törvény, a lelkiismereti és vallásszabadságról, valamint az egyházakról szóló 1990. évi IV. törvény (a továbbiakban: Lvt.) 9. \$ (1) bekezdése és 12. \$ (1) bekezdése alapján az egyház nyilvántartásba vételéröl a székhelye szerint illetékes megyei bíróság, illetőleg 
dokumentumok alapján felsejlett egy törvényes és legalább elemi vallási tartalmakat is rögzítő cél, úgy a nyilvántartásba vétel - az esetek kivételt alig felmutató többségében - automatikusan megtörtént.

Az első - az érdemi szigorítás irányába elmozduló - szabályozási kísérlet $a$ lelkiismereti és vallásszabadság jogáról, valamint az egyházak, vallásfelekezetek és vallási közösségek jogállásáról szóló 2011. évi C. törvény volt, amelyet azonban az Alkotmánybíróság közjogi érvénytelenség miatt alkotmányellenesnek nyilvánított, és ezért megsemmisitett. ${ }^{45} \mathrm{Nem}$ kitérve az elmúlt tíz év valamennyi jogalkotási fejleményére, az mindenképpen jól látható, hogy 2010 után a nagyobb, történelmi, illetve „bevett” egyházak „helyzetbe hozására” irányuló jogalkotási törekvéseket az $A B$ tevékenysége több ízben is korrigálta. ${ }^{46}$

Az új Ehtv. eredeti modellje (s részben a mostani is) egy értékválasztó finanszírozási modell, amely tudatosan nélkülözi az állami semlegességet, amennyiben egyebek mellett - mind az egyházi státusz elnyerését (s ezen keresztül egyes anyagi természetü előnyök biztosítását ${ }^{47}$ ), mind pedig a Kormánnyal kötött (köthetö) megállapodás tényét alapvetően a döntésre jogosult állami szervek (Országgyűlés, Kormány) belátására bízta, oly módon, hogy egyúttal a döntéssel érintettek számára nem biztosít(ott) érdemi jogorvoslat lehetőséget. ${ }^{48}$

a Fővárosi Bíróság határozott, nemperes eljárásban, gyakorlatilag automatizmussá téve az eljárást.

${ }^{45}$ A törvény megszületésének - látszólagos, a médiumokban kommunikált - kiváltó oka az a 200o-es évek végétől elharapódzó gyakorlat volt, amelynek keretében magánfenntartású idősek otthonai - döntően az általuk gondozottak bevonásával, de tényleges vallási tevékenység folytatása nélkül - egyházzá alakultak, ily módon szert téve az ún. egyházi kiegészítő normatívára is.

${ }^{46}$ Lásd részletesebben: Köbel Szilvia: „Az Alkotmánybíróság vallásszabadsággal és vallási közösségekkel kapcsolatos gyakorlata." In uő (szerk.): Az állami és a felekezeti egyházjog alapjai, Budapest, Patrocinium, 2016, 207-234.

${ }^{47}$ A volt egyházi ingatlanok tulajdoni helyzetének rendezéséről szóló 1991. évi XXXII. törvény által szabályozott folyamatokon túl ma a legfontosabb, az egyházakat megillető jogosultságok a személyi jövedelemadóról szóló 1995. évi CXVII. törvény 1. sz. mellékletében megjelenő, az egyházi tevékenységgel kapcsolatos juttatásokból származó bevételek (adományok, segélyek, ajándékok, ellátások stb.) adómentessége; a rendelkező nyilatkozatot tevő magánszemélyek által befizetett személyi jövedelemadó egy százalékára való jogosultság; az egyházak szociális, egészségügyi és kulturális intézményeinek - a normatív támogatásokon felül - juttatott ún. kiegészítő támogatás intézménye; az egyházi épületek rekonstrukcióját, valamint egyéb egyházi célú beruházásokat támogató központi költségvetési előirányzatok léte, vagy éppen a kistelepüléseken szolgálatot teljesítő lelkészek jövedelmének jövedelempótlék formájában történő állami kiegészítése.

${ }^{48} \mathrm{Az}$ Emberi Jogok Európai Bíróságának (a továbbiakban Bíróság, EJEB) héttagú kamarája 2014. április 8-án 5:2 arányban elmarasztaló ítéletet hozott Magyarországra nézve 17, egyházi státuszát a lelkiismereti és vallásszabadság jogáról, valamint az egyházak, vallásfelekezetek és val- 
Általánosabb megközelítésben - egyúttal politikatudományi kontextusban mindezen hatás(mechanizmus)ok a kormányzati populizmus és egyházak témakörben (cím alatt) is megragadhatóak.

Egy korábbi tanulmányunk szűkebb tárgya a 2010-es évek két, Magyarországon külön-külön is izgalmas jelenség-együttesének kapcsolata volt: azt vizsgáltuk, hogy a civil társadalom állapota és formaváltozásai hogyan függnek össze az ún. politikai populizmussal, kiváltképp a nemzetközi vitákat is generáló 'illiberális' állam jelenségeivel. ${ }^{49}$ A civil társadalom hagyományos jellemzője Magyarországon, hogy sérülékeny és reaktivv, mert tőkehiányos, és hiányoznak az egyszintüség irányába mutató kapcsolatok. ${ }^{\circ}$ Azt látjuk, hogy a civilek érdekfeltáró és érdekmegjelenítő szerepe egy szinte kizárólagosan reaktív formában érvényesül. Ez alatt azt értjük, hogy a politikai akarat formálásának folyamatában rendelkezésre állnak ugyan a

lási közösségek jogállásáról szóló 2011. évi CCVI. törvény alapján (Ehtv.), 2012. január 1-jén, illetve 2012. március 1-jén elveszítő vallási felekezet egyesített panaszai tárgyában. A Bíróság arra a következtetésre jutott, hogy a magyar állam a kérelmezők vonatkozásában megsértette az Emberi Jogok Európai Egyezményében (a továbbiakban: egyezmény) biztosított egyesülési jogot (11. cikk) a vallásszabadsághoz való joggal (9. cikk) összefüggésben, tekintve, hogy a jogszabály csak a mellékletében felsorolt „bevett egyházak” egyházi státuszát ismerte el, a többi, korábban egyházi státusszal rendelkező szervezet pedig egyesületi minősítést kapott, miközben az egyházzá minősítést az Országgyülés egyúttal a bíróságok hatásköréből saját hatáskörébe vonta. Az EJEB az eset és az érvek vizsgálata során kifejtette: a vallás és lelkiismereti szabadság biztosításához hozzátartozik, hogy az állam független marad, és pártatlan szabályozást alakít ki a vallási közösségek tekintetében. Véleménye szerint azáltal, hogy a parlament hatáskörébe vonta, mely vallási közösségeket nyilvánítja egyházzá, megsértette az egyezmény 9. cikkét (a bíróság a Metropolitan kontra Besszarábia-ügyre hivatkozott). Az EJEB a továbbiakban a 9. cikk 2. szakasz fennállását vizsgálta; tehát azt, hogy a korlátozás törvényben meghatározott-e, illetve arra a közbiztonság, a közrend és a közegészség vagy a közerkölcs, illetve mások jogainak és szabadságainak védelme érdekében került-e sor. A bíróság megállapította a 2011. CCVI. törvény korlátozó voltát. Továbbá: álláspontja szerint az állami pénzekkel való visszaélés megakadályozása mint közérdekủ cél megállja ugyan a helyét, ám a bíróság arra a következtetésre jutott, hogy a korlátozás nem arányos az elérendő céllal, tekintettel arra, hogy a magyar állam intézkedése eltúlzott és felettébb szigorú. Magát a közérdeket azonban nem vonta kétségbe Strasbourg, csupán egy enyhébb, a vallási közösségekkel jobban együttmüködő és az Országygyưléstől függetlenebb szabályozást tartott indokoltnak. Utóbb, a korábban megállapított jogsértések miatt vagyoni és nem vagyoni kártérítést ítélt meg több panaszos tekintetében az EJEB 2016. o6. 28-án. A megítélt kártérítések 40 ooo és 140 ooo euro közötti összegűek voltak. Forrás: Rixer Ádám: „Az állam és a vallási közösségek kapcsolata a mai Magyarországon. A vallási közösségek nyilvántartása és pénzügyei a jogi szabályozás tükrében." Államtudományi Mühelytanulmányok, I, 2017/1, 1-35, ezen belül 17.

${ }^{49}$ Rixer Ádám: „A civil társadalom helyzete Magyarországon, különös tekintettel a populizmus térnyerésére." Glossa Iuridica, V, 2018/3-4, 43-72.

${ }^{50}$ Ágnes Kövér: „Captured by Church and State: Civil Society in Democratic Hungary.” In P. Krasztev - J. Van Til (szerk.): Hungarian Patient. Budapest, CEU Press, 2015, 81-90. 
különböző - a jog által biztosított - lehetőségek a civilek (és az általuk képviseltek) véleményének kikérésére (lásd pl. az elözetes hatásvizsgálat intézményét, illetve a jogszabálytervezetekkel kapcsolatos kötelező véleményezést), de a gyakorlatban a legnagyobb jelentőségü jogszabályok is gyakran jogsértően, az érintettek kihagyásával, illetve (ez a leggyakoribb) jogszerűen, az érintettek formális bevonásával (javaslataikat figyelembe nem vevő módon) kerülnek elfogadásra. ${ }^{51}$ Azt mondhatjuk, hogy a jogszabályi környezet fejlettsége Magyarországon egyelöre magasabb, mint az azt müködtető politikai és igazgatási kultúráé.

A hazai és nemzetközi szakirodalom is gyakran említi a 'jó és rossz civil szervezetek' szerinti fekete-fehér állami látásmód erősödését 2010 után, amennyiben a hivatalosan a közérdekre alapított szükítések, szigorítások, korlátozások egyes civil jellegü szereplők - például vallási szervezetek, humán szolgáltatók, migrációs szervezetek, félkatonai szervezetek stb. - vonatkozásában erősödő állami beavatkozást mutattak/mutatnak az 1990 és 2010 közötti időszakhoz képest. Valamifajta jogi és politikai homogenizációs folyamat zajlik (az állami nézőpontból „rossz egyháznak" minősülő entitásra példa a metodista gyökerü Magyarországi Evangéliumi Testvérközösség). ${ }^{22}$

$\mathrm{Az}$ állami beavatkozás egyik mögöttes oka a vizsgált szférában is egy újkonzervativ ideológia megalapozásának, illetve uijjáépitésének szándéka - s ennek részeként a keresztény erkölcs alapjainak erősítése az oktatásban, illetve egyes bevett egyházak kiemelt támogatásával. A területet érintő „szakpolitika” hangsúlyos eleme a múltépités, amelynek része Magyarország Alaptörvényének megalkotása és folyamatos módosítása is ${ }^{53}$ - nem utolsó sorban a keresztény kultúrával kapcsolatos követelmények expressis verbis megjelenítése révén. Ennek a tágabb közpolitikai trendnek része a muszlim vallással és kultúrával szembeni erőteljes kiállás, elsődlegesen általánosító módon, az egyes szélsőséges jelenségeket kiemelő formában, de a hazai muszlim közösségek (entitások) említése, a velük kapcsolatos közvetlen uszítás nélkül.

\footnotetext{
${ }^{51}$ Rixer Ádám: „A hatásvizsgálatok jelentősége és egyes szempontjai a vallási szervezetek szabályozása körében." Kodifikáció, II, 2013/1, 89-101, ezen belül 95.

${ }^{52}$ metegyhaz.hu (2020. 11. O4.) Az állammal fennálló konfliktus kapcsán lásd: „Tavaszig nyertek időt Iványi Gáborék a gázszolgáltatónál.” hvg.hu, 2020. szeptember 24. hvg.hu/itthon/20200924_ivanyi_gabor_oltalom_gaz_tartozas_kozmuvek. (2020. 11. 04.) Lásd továbbá: Mártonffy Marcell: „A Magyarországi Evangéliumi Testvérközösség szolgálata.” Egyházfórum, XXXI, 20I6/3, 3-I6.

${ }^{53}$ Rixer Ádám: „A történeti alkotmány vívmányai: Utazás a múltba vagy út a jövőbe?” Balogh Judit et al. (szerk.): 65. Studia in honorem István Stipta. Budapest, Károli Gáspár Református Egyetem Állam- és Jogtudományi Kar, 2017, 365-375; illetve Rixer Ádám: A vívmány-teszt. Budapest, Dialóg Campus Kiadó, 2018.
} 
A fentebb emlitett civilellenesség egyúttal a politikai tér kisajátitásával is együtt jár, s a civil társadalom egészének helykeresését is eredményezi: „a tilalom-határok megsokszorozódnak, a bázisközösségek pedig mikrohálózati szférába húzódnak vissza [...] Egyszóval: a hatalom által kisajátított politikai térben adott esetekben és időszakban főszerepet kaphatnak olyan társadalmi (civil, önjelölt, helyi, érdekcsoportos, képviseleti, nem-intézményes) önreprezentációk, melyek a napi sajtóban és a föútvonalakon is az „utca szintü politizálás” [...] alakjában jelennek meg, [...] új mozgalmak, állandósult demonstrációk, petíciózások, önkéntes megtagadási játszmák, melyek az ismét ébredező civil társadalom előjelei [...]".54

Mindehhez újfent tegyük hozzá, hogy a hatályos jog komoly pénzügyi, gazdasági természetű többletjogosultságokat, illetve azok lehetőségét biztosítja az Ehtv. kitüntetett státusú közösségtípusai számára. ${ }^{55}$

\section{II.4. A NEGYEDIK OKCSOPORT: SPECIÁLIS ÉS VEGYES OKOK}

A fentiek mellett lehetnek egészen „speciális, nem fősodorbeli” okok is, tudniillik az új entitások létrehozása mögötti meghúzódó okok között. Így például etnikai vagy más hasonló szempontok is, melyek közül az alábbiakban csupán példálódzó jelleggel emelünk ki néhányat. $S$ természetesen az esetek jelentős részében (többségében) többes, azaz vegyes okokról adhatunk számot, mikor is egyidejűleg több szempont, tényező érdemben is szerepet játszik e változásokban...

\section{ETNIKAI SZEMPONTOK}

„Sajátos jelensége a rendszerváltás utáni magyarországi „vallási közéletnek”, hogy különösen vidéken egyre-másra jöttek létre a romák által és elsősorban romáknak létrehozott vallási közösségek, melyek közül több is szert tett egyházi státuszra. Ilyen volt pl. - hogy csak az ismertebbeket említsük - az Új Élet Roma Egyház, illetve a Jézus Krisztus Magyarországi Roma Keresztény Egyház. Ezek a szervezetek olyan integratív, szocializációs és reszocializációs feladatokat is ellátnak/elláttak,

\footnotetext{
${ }^{54}$ Gergely András: „Kisebbségben: a »civil társadalom« másképp közelítése.” MASZOL, 2017. 07. 20., 172. maszol.ro/index.php/kisebbsegben/83580-kisebbsegben-a-civil-tarsadalom-maskeppkozelitese (2020. 09. 05.).

${ }^{55}$ Lásd részletesebben: Ormóshegyi Zoltán - Rixer Ádám: „Magyarországi vallási közösségek pénzügyi forrásai és gazdálkodása a jogi szabályozás tükrében.” In Köbel Szilvia (szerk.): $A z$ állami és a felekezeti egyházjog alapjai. Budapest, Patrocinium, 2016, 176-207.
} 
amelyeket a nagyobb egyházak és a hasonló céllal működő állami intézmények valós kapcsolódási felületek hiányában képtelenek ellátni vagy csak részlegesen látnak el" - írtuk korábban. ${ }^{56}$

Noha e tanulmány elsődlegesen a magyarországi folyamatokra kíván rámutatni, ám az etnikai ok, mint a vallási közösségek létrejöttében, fennmaradásában és átalakulásában is döntő szerepet játszó tényező, jelen van a határon túli magyar közösségek életében is - különösen a Kárpát-medence egyes régióiban. ${ }^{57}$ Amenynyiben vizsgálódásunk körét kiterjesztjük a földrajzi-politikai határokon túlra is, úgy újabb frontvonal nyílhat a kutatásban...

\section{A VALLÁSI KÖZÖSSÉG JOGI ÉRTELEMBEN VETT „MEGTÖBBSZÖRÖZŐDÉSÉT”, PÁRHUZAMOSAN LÉTEZŐ ENTITÁSOKBAN VALÓ LÉTEZÉSÉT EREDMÉNYEZŐ OKOK}

Szintén speciális esetköre az új vallási csoportoknak a nem tisztán vallási entitások vallási közösségek általi létrehozása. Elsősorban adózási és más pénzügyi, számviteli stb. szempontok miatt a vallási közösségek jelentős része maga is létrehoz gazdasági, szolgáltatási célok ellátására alapítványokat, ritkábban egyesületeket vagy gazdasági társaságokat. Tipikus forma a vallási közösség által fenntartott humán közszolgáltatási intézmény. Így egytestü, de kétfejű entitások jönnek létre, melyeket összeköt az alapítók személye, a közös célok iránti elkötelezettség és a működések praktikus összehangolása is - miközben jogi értelemben elvileg külön szereplőkről beszélünk. A százszámra felhozható példák közül említsük meg a Szombathelyi Evangélikus Egyházközség Szeretetszolgálatért Alapítványát.

A fenti megkettőződés sajátos - közvetettebb - formája az, amikor valamilyen „vallási színezetü” kezdeményezés, félig politikai-félig vallási entitás jön létre. Ilyennek tekinthetjük például a nevükben is vállaltan keresztény pártokat, keresztény értékeket harcosan képviselö egyéb kezdeményezéseket (tipikusan egyesületeket, ritkábban alapítványokat), „átmeneti” képződményeket, amelyek esetében a

\footnotetext{
${ }^{56}$ Rixer: „A hatásvizsgálatok jelentősége”, 96.

${ }^{57}$ Radvánszky Ferenc: „Megtörő kegyelem. Avagy, a Kárpátaljai Református Egyház (KRE) előtt álló kihívások és látható irányai, különös tekintettel a KRE struktúrájára és demográfiai tendenciáira." Szellem és Tudomány, VIII, 2017/Klnsz., 195-214. További irodalom a határon túli magyarság és a református egyház speciális kapcsolatához: Czagány Gábor: „A református hagyományok, mint a társadalmi identitás kifejezőeszközei a Kárpát-medencében.” Deliberationes, IV, 2011/2, 49-72; id. Hegedűs Lóránt: „A református ökumené szerepe a Kárpát-medencében." Confessio: a Magyarországi Református Egyház figyelöje, XVII, 1993/3, 17-21. Lásd továbbá Gabriel Andreescu: „Vallási élet Romániában: Semleges szabályozás, pártos gyakorlat.” Egyházfórum, XXXIII, 2018/2, 23-37.
} 
közös vallás (illetve az ún. kulturális közösséget megalapozó hagyomány azonossága) az összekötő kapocs, anélkül azonban, hogy egyéni, illetve közösségi vallásgyakorlás (annak előmozdítása) vagy klasszikus humán közszolgáltatások nyújtása akár közvetve is kapcsolódna az új közösséghez. E körben elsősorban egyes politikai szereplők által létrehozott, ,gründolt”, saját politikai holdudvarukat bővítő, saját civil bázisukat erősítő kezdeményezések jelenhetnek meg.

\section{FelsZABAdítÁSI TEOLÓGIA ${ }^{58}$}

Néha nem csak a politika nyit a vallási szervezetek és azok tagsága felé, de ennek fordítottja is megfigyelhető, amikor a vallás politikai babérokra tör, s világi politizálásba fordul - és teológiája is mintegy feloldódik a világi típusú politizálásban. Ennek politikai, teológiai vagy éppenséggel szervezeti implikációi Magyarországon igencsak szerény mértékűek, ezzel együtt - általános jelentősége miatt, illetve lehetséges erősödése okán - a jelenség e tanulmányban is említendő. „Különösen a szegényebb országokban volt megfigyelhető a '9o-es években, hogy némely teológia a felszabadítás szekularista programjának hatása alá került; azok a maguk immanens és kizárólagosan földi szempontjaival befolyásolják e teológiákat. Pedig e programok nem látják, és nem is láthatják, hogy keresztény szemszögböl a »felszabadítás « mindenekelőtt és főképpen a bűn alapvető rabságából való kiszabadulást jelenti, amit a »világ" nem is ért meg, sőt egészen a tagadásáig megy" ${ }^{{ }_{9} 9}$ Ratzinger külön utal arra, hogy ez az irány gyakran együtt jár a bibliai szövegek önkényes kezelésével is. ${ }^{60} \mathrm{~A}$ teljesebb kép érdekében meg kell jegyzenünk azt is, hogy az elmúlt bő két évtizedben a felszabadítási teológia újdonsága és kívánatossága jelentősen megkopott a Katolikus egyházon belül is ${ }^{61}-$ miközben egyébként a szegényekről való gondoskodás más összefüggései kifejezetten elötérbe kerültek.

Összegezve a fent elmondottakat, azt látjuk, hogy a felszabadítási megközelítések jelentős hányadában egy lehetséges következmény (emberi jogok nagyobb tisztelete, garantált érvényesülése, végső soron kivívása) öncéllá válik - leválva a közvetlen bibliai, üdvösséggel összefüggö lelki alapcélokról. Ez volt az a veszélyes irány, amire Jézus tanítványai is ráléptek, mikor egy evilági állam uralkodóját vizionálták Jézusban: csodáit, törekvéseit is eszköznek vélve a hatalom megragadásának folya-

\footnotetext{
${ }^{58}$ Bővebben lásd: Rixer Ádám: „A keresztény szabadság jogi és teológiai fogalma.” Acta Humana, VIII, 2020/3, 139-168.

${ }^{59}$ Joseph Ratzinger: Beszélgetés a hitről Vittorio Messorival. Budapest, Vigilia, 1990, 151.

${ }^{60}$ Uo. 164 .

${ }^{61}$ Lánszki Béla: „A felszabadítási teológia ideje lejárt?” Credo - evangélikus folyóirat, V, 1999/3-4, $69-75$.
} 
matában. Jézus azonban - mellőzve a képletes beszédet - teljesen világossá teszi, hogy küzdelme nem a világi hatalom megszerzésére, politikai vagy kifejezetten katonai jellegü csaták megvívására irányul, hanem lelki típusú, adakozásra összpontosító, egyenesen önfeladó életmódot és küldetést jelent. ${ }^{62}$

\section{VEGYES OKOK}

Végül külön is érdemes szólnunk a több forrásból (tanításból, hagyományból, rítusból stb.) táplálkozó vallási csoportokról, melyek létrejöttének okai a vegyes okok (és hatások, eredmények) között is említhetőek. Povedák kiemeli például, „[H]ogy egyetlen vallás sem létezik kizárólag leírt, esszenciális állapotában, hanem a mindennapi kultúrában az adott korszak kulturális körülményeit, egy-egy régió, nemzet történelmi, politikai sajátosságait, de a hívek egyéni igényeit is tükrözve reprezentálódnak. Ez a mechanizmus egy olyan szinkretikus vernakuláris vallásosság meglétét feltételezi minden korszakban, melyben az uralkodó vallási kánon mellett attól idegen, ideológiai szinten azzal gyakran össze nem illeszthető elemek ötvöződnek, az egyének számára az esetek többségében nem is tudatosulva. Így voltak megtalálhatók régiónkban a korábbi korszakok népi vallásosságában kereszténység előtti elemek, és így kerültek a kortárs vernakuláris vallásosságba is keleti filozófiákat tükröző vagy éppen az egykori táltos-hit elemeit revitalizálni kívánó trendek." 63

\footnotetext{
${ }^{62}$ Lásd Ef 6,12: „Mert mi nem test és vér ellen harcolunk, hanem erők és hatalmak ellen, a sötétség világának urai és a gonoszság lelkei ellen, amelyek a mennyei magasságban vannak" (Magyar Bibliatársulat újfordítású Bibliája [2014]); továbbá, legegyértelműbb példaként: „Akkor odament hozzá Zebedeus fiainak anyja a fiaival együtt, leborult előtte, és kérni akart tőle valamit. Jézus megkérdezte tőle: Mit kívánsz? Ỏ így felelt: Mondd, hogy melletted üljön az én két fiam a te országodban, az egyik jobb kezed, a másik bal kezed felől. Jézus így válaszolt: Nem tudjátok, mit kértek. Kiihatjátok-e azt a poharat, amelyet én fogok kiinni? Ök így feleltek: Kiihatjuk. Erre ő ezt mondta nekik: Az én poharamat kiisszátok ugyan, de hogy ki üljön jobb és bal kezem felöl, azt nem az én dolgom megadni. Azoké lesz, akiknek az én Atyám elkészítette. Amikor ezt meghallotta a többi tíz, megharagudott a két testvérre. De Jézus magához hívta őket, és ezt mondta: Tudjátok, hogy a népek felett zsarnokoskodnak fejedelmeik, és vezetőik hatalmaskodnak rajtuk. De közöttetek ne így legyen, hanem aki naggyá akar lenni közöttetek, az legyen a szolgátok, és aki közöttetek első akar lenni, az legyen a rabszolgátok. Mert az Emberfia sem azért jött, hogy neki szolgáljanak, hanem hogy ő szolgáljon, és életét adja váltságul sokakért." (Mt 20,20-28; Magyar Bibliatársulat újfordítású Bibliája [2014].)

${ }^{63}$ Povedák István: „Láthatatlan határok. A keresztény - újpogány szinkretizmus.” In uő - Szilárdi Réka: Sámán sámán hátán. A kortárs pogányság multidiszciplináris elemzése. Szeged, MTASZTE Vallási Kultúrakutató Csoport - SZTE Néprajzi és Kulturális Antropológiai Tanszék, 2014, 55 .
} 


\section{AZ ÚJ VALLÁSI CSOPORTOK SZERVEZETE ÉS TEVÉKENYSÉGE}

Egymagában a lehetséges okok összegyüjtése és szemrevételezése nem feltétlenül elegendő ahhoz, hogy valós képet kapjunk az új csoportokról, mozgalmakról - különösen azok tényleges súlyáról, hatásáról. Ehhez legalább két további szempont, a szervezet és a hétköznapi működés (tényleges tevékenység) áttekintése és legalább elemi szintü értékelése is szükséges. Jelen fejezet két alfejezetében tehát arra teszünk kísérletet, hogy a főbb, ma meghatározó, domináns - az 5. fejezetben bemutatott egyes speciális esetkörökön túlmutató - példákat összegyüjtsük és rendszerezzük - a tipikus esetekre koncentrálva.

\section{III.1. A SZERVEZET JOGI FORMÁJA, BELSÖ FELÉPÍTÉSE, MÜKÖDÉSE}

Lényeges kérdés, hogy egy vallási közösség milyen szervezetben, illetve a szervezettség mely fokán létezzen, működjön. Néhány esetben a vallási szférában is viszszaköszönt a nyolcvanas-kilencvenes évek fordulójának politikai alapdilemmája: párttá válni, azaz „intézményesülni” vagy megtartani a rugalmasabb mozgalmi jelleget? E dilemma - mármint az intézményesülésből adódó problémák felvállalása - tehát megjelent a vallási életben is, bár a kilencvenes évek hirtelen támadt szabadsága és a rendkívül könnyű egyházalapítás, és az azzal nyerhető jogi, pénzügyi előnyök a legtöbb esetben gyorsan eldöntötték a vitákat...

A minket körülvevő valóság - így a vallási szféra - elemeire, jelenségeire is igaz, hogy azok legkönnyebben jogi úton egyneműsíthetőek, azaz az első szemrevételezésből fakadó érdemi leírási kísérlet (még ha az nem is teljeskörü) gyakran a jogé: az Ehtv., azaz a lelkiismereti és vallásszabadság jogáról, valamint az egyházak, vallásfelekezetek és vallási közösségek jogállásáról szóló 2011. évi CCVI. törvény 7. \$ (1) bekezdése értelmében „Vallási közösség müködhet jogi személyiség nélkül, valamint jogi személyiséggel rendelkező szervezeti formában", továbbá a (2) bekezdés alapján „Jogi személyiséggel rendelkező vallási közösség $a$ ) a vallási egyesület, $b$ ) a nyilvántartásba vett egyház, $c$ ) a bejegyzett egyház és $d$ ) a bevett egyház. A (3) bekezdés mind a négy forma tekintetében kijelenti, hogy az „azonos hitelveket valló, természetes személyekből álló, önkormányzattal rendelkező autonóm szervezet."

Szűkebb témánk szempontjából különösen lényeges, hogy a 11. $\$(1)$ bekezdése értelmében „A bevett egyház, a bejegyzett egyház, illetve a nyilvántartásba vett egyház belső szabálya szerint jogi személyiséggel rendelkező egysége, szervezete vagy intézménye jogi személy." Utóbbi lehetőség tehát az egyesületi formában müködő vallási közösségeket nem illeti meg. 
Az elmúlt évtizedek új hazai közösségeit és mozgalmait szervezeti szempontból rendszerezve, az alábbi csoportosítás adja magát:

1. A hagyományos vallási szervezeteken belüli és azok keretei közül kilépni nem is szándékozó „megújulási mozgalmak”, új csoportok, közösségek leggyakrabban egyesületi formában, esetleg egy alapítvány égisze alatt szervezett tevékenység keretében, ritkábban pedig ún. belső egyházi jogi személyként jöttek/jönnek létre - szinte mindig egy szűkebb, jól körülírható speciális cél, törekvés megvalósítása érdekében. Természetesen itt is lehetséges a jogi személyiség teljes hiánya (bár erre nemigen látunk példát).

A legismertebb „tétel” a nagy egyházakon belüli új közösségek köre, melyek között is az elmúlt évtizedekben a legnagyobb ismertségre a katolikus bázisközösségek tettek szert: a Bokor, a Regnum Marianum, a Katolikus karizmatikusok csoportja. Ezek különböző mértékben intézményesültek, illetve működési formáik között is eltérések mutatkoznak. A Bokor például önmeghatározása szerint „katolikus gyökerü, a jézusi szeretet-eszményt képviselő emberek testvéri társasága, erkölcsi megújulási mozgalom," amelyet egy egyesület, a Bokor Közösségfejlesztő Kulturális Egyesület fog össze. ${ }^{64}$ E körben említhető a nemzetközi ökumenikus szeretetközösségként létrejött Taizéi közösség is, amely maga is a bármely okból üldözöttek segítését és a kiengesztelődést középpontba állító mozgalom.

2. Az új - azaz közvetlen elözmények nélküli - közösségek esetében is adják magukat a jogi személyiségű és jogi személyiség nélküli formák, azzal a szükségszerű megjegyzéssel, hogy egyes formák - a komoly törvényi többletfeltételek miatt - általában nem jöhetnek szóba, ${ }^{65}$ így ezekben az esetekben az egyesületkénti működés a reális alternatíva.

Sajátos - leginkább e ponthoz sorolható - jelenség az ún. Felház mozgalom, amelyet egyebek mellett az különböztet meg a hasonló jelenségcsoportoktól, hogy egyetemisták alapították, határozott időre (!), és elsősorban nagyobb léptékü (ezres nagyságrendű) dicsőítő alkalmakon keresztül létezett. A Felház sokáig a Kelet-Európai Utógondozottakért és Lakóotthonokban Lakókért Alapítvány (KUL) égisze alatt működött, annak egy alszámláját használva, egy ideig tudatosan kerülve az önállósulást, az „intézményesülést”. 2019-re „kinőtte magát”, szétfeszítette a saját maga által teremtett kereteket: az addigiakat egy többszereplős, decentralizáltabb forma, a Felház Dicsőítő Mozgalom, az ún. Házi Felházak rendszere és az ún. Uta-

\footnotetext{
${ }^{64}$ bokorportal.hu/miabokor.php (2020. 10. 11.).

${ }^{65}$ Lásd az Ehtv. 9/D., 9/E., 9/F. és 9/G. \$-ait a nyilvántartásba vett, bejegyzett és bevett egyházak esetében megfogalmazott törvényi többletkövetelményeket.
} 
zó Szolgálat váltotta fel, országos lefedettséggel. Lényeges, hogy utóbbi törekvések sem szüntették meg az alapvetően felekezetközi jelleget - legalábbis egyelöre.

3. Az ún. lelkiségi mozgalmak esetében elmondható, hogy azok az 1. pontban említett formák mellett gazdasági társasági formában szervezett entitások keretei között (illetve azok segítségével) is működtek/működnek. Speciális, időszaki jellegük miatt gyakran a formalizáltság és informalitás határán mozognak. A hazai keresztény lelkiségi mozgalmak sajátja, hogy a keresztény értékek közül egyet-kettöt emelnek ki, és azokra szerveznek mozgalmat: ilyennek tekinthetö hazánkban a Kolping, a Házas Hétvége vagy éppen a Cursillo nevü „lelki alapozó tanfolyam” hétvégenként.

4. Kevéssé jelentős, de külön említendő tényező az „egyszemélyes intézmények”, önjelölt próféták, vallásalapítók, állítólagos Jézus-reinkarnációk megjelenése a vallási piacon. Közös jellemzőjük, hogy állítólagos csodák, gyógyulások, jelek kísérik őket, növekvő elutasítottság és időszakos fizikai jelenlét, illetve folyamatos vándorlás és jogi típusú konfrontációk mellett. Ezen jelenségek mögött - nem kizárva, hogy egyes esetekben helyes meggyözödések és azokhoz kapcsolódó biblikus vallási gyakorlatok is kapcsolódhatnak egy-egy „egyszemélyes intézménnyé váló” vallási vezetőhöz - gyakran mentális betegségek kiteljesedése vagy kifejezetten anyagi típusú haszonszerzési vágy bújik meg mögöttes okként.

Ezek példái kevéssé dokumentáltak a szakirodalomban, de „Dénes Próféta” és néhány hozzá hasonló „szerzet” be-bekerül a hazai irodalomba is. ${ }^{66}$ Ezekben az esetekben a szervezeti forma - ha egyáltalán felmerül ilyesmi - esetleges, véletlenszerü, illetve külső körülmények által determinált.

A megújulás szervezeti formáinak katalogizálása, - ideértve annak lehetséges jogi formáit - önmagában nem feltétlenül ad elegendő információt egyes lényeges tartalmi kérdésekről: korunk egyik jellemzője ugyanis azon vallási, civil nonprofit és forprofit tényezők, elemek keveredése, melyek valamilyen karitatív és/vagy oktatási tevékenységben sűrűsödnek össze: ilyen például a rövid idő alatt robbanásszerü sikert elérő keresztény szemléletü coaching továbbképzés, amely nem önálló mozgalom, de érdemben befolyásolja a hazai spirituális, vallási stb. közéletet, illetve annak átalakulását is. Hasonló, „atipikus képződmény” az Ez az a nap! mozgalom és rendezvénysorozat, amelynek célja, hogy évről évre összegyüjtse a keresztényeket és Istent keresőket egy nagyszabású dicsőítő rendezvényre Magyarország szívében. Teszi mindezt felekezetközi szervezésben és nemzetközi jelleggel,

${ }^{66}$ László Koppány Csáji: „How to Become Fundamentalist (A Hungarian charismatic prophet’s new religious movement in the Carpathian basin - an anthropological discourse analysis)." Sociology International Journal, II, 2018/3, 160-169. 
a tevékenység gazdasági aspektusainak megfelelő alapítványi formában („Ez az a nap!" Alapitvány), számos egyéb formájú vallási szervezettel együttmüködve (pl. Magyar Evangéliumi Aliansz).

Egyébként is jellemzője a vallási megújulásnak - s nem csupán a keresztény szemléletű törevésekben - a tanfolyami jelleg előtérbe kerülése, azaz a rövid időtartamú, tipikusan hétvégi képzések elterjedése, amelyek egy témában egy vagy legfeljebb néhány alkalmas képzések során adnak elméleti és/vagy praktikus információt, bibliai alapokat és azokhoz kapcsolt gyakorlati példákat, nem ritkán helyzetgyakorlatokkal mélyítve a megszerezhető tudást. Mindez már át is vezet minket az újabb mozgalmak tipikus tevékenységeihez, melyekről a következő alfejezet szól.

\section{III.2. A NEM VISSZAÉLÉSSZERÜ MEGÚJULÁS KÜLSŐ JELEI, TARTALMA, TEVÉKENYSÉGI FORMÁI}

A legfontosabb kérdés persze nem a forma, azaz a választott jogi forma, hanem a tényleges, gyakorlati müködés. A megújulásnak - bármilyen megújulásról legyen is szó - mindig ez az egyik leghangsúlyosabb része: mi az, ami ténylegesen zajlik a teológián, a hirdetett tanokon innen és túl egy adott vallási közösségben. Melyek a tipikus, esetleg újszerű működési formák, a kívülről is érzékelhető, illetve kifelé is képviselt minták, konkrét cselekvésmódok, amelyek jellegadóak - azaz alkalmasak általánosító következtetések levonására is?

Magyarországon az 1980-as évek legvégén bekövetkezett mélyreható változások óta

a) egyrészt szabadon gyakorolhatóvá, másrészt ténylegesen is gyakorolt tevékenységgé vált a keresztény közösségek által kezdeményezett és közvetlen evangelizáció utcán (közterületen), és kisebb mértékben lakóházakban, illetve egyéb magánterületeken is. Ezzel kapcsolatban itt is meg kell jegyeznünk, hogy a '9o-es évek vége óta visszaesés tapasztalható az ún. utcai evangelizációban. Ennek okai között - egyéb, szervezetspecifikus okok mellett -, az ún. vallási átfertőződöttség mértéke is felvethető. A COVID-19 átfertőződöttség mintájára a vallási típusú átfertőződöttség is arra utal, hogy bizonyos mérték fölött sajátos közösségi immunitás alakul, vallási vonalon leginkább amiatt, mert a dolog újdonsága elveszett, az információk elérhetőek, és a korábban használt információs csatornák is „telítődtek” (azaz az adott kérdéskörről valamifajta vélt vagy valós tudással már mindenki rendelkezik egy ponton). Ez persze - teológiai nézöpontból - csak annyit jelent, hogy új típusú eszközökre van szükség, hiszen Isten ugyanaz, és ugyanaz a célja is, tudniillik, 
„hogy minden ember üdvözüljön, és eljusson az igazság megismerésére” $(1 \operatorname{Tim} 2,4)$;

b) felfutott a nyílt, keresztény közösségek által kezdeményezett és közvetlenül látogatható (hozzáférhetö) közösségi alkalmak szervezése. Nemcsak hagyományos formákban (istentiszteletek, bibliakörök stb.), hanem lelki hétvégék (házasság, gyermeknevelés, böjt, közös Bibliaolvasás, ima, időbeosztás témákban, illetve klasszikus lelkigyakorlatok formájában), illetve zenei - és ritkábban más müvészeti ágakban szervezett - alkalmak keretében. Ezek megvalósulási formái számos vonatkozásban igazodnak a modern, szerepekben élő ember elvárásaihoz, igényeihez, a modern társadalom mintáihoz is...

A fenti alkalmak formái között egyre gyakrabban szerepelnek a nyílt, keresztény közösségek által kezdeményezett és közvetetten, médiumokon keresztül megvalósuló üzenetközvetítési módozatok is. Ennek az új típusú jelenlétnek a leggyakoribb formája a vallási alkalmak közvetítése (ritkábban televízió: pl. PAX TV, ATV; gyakrabban Facebook közvetítés formájában) vagy utólagos hozzáférhetővé tétele. Az említett esetekben a választott megoldás általában járulékos, kiegészítő jellegü szolgálatként (szolgáltatásként) jelenik meg, kiterjesztve az egyes lelki alkalmak hívek, érdeklődők általi elérhetőségét. Az értékmegjelenítés további, részben közvetett formái a könyvek és egyéb hordozók kiadása, forgalmazása, miközben ezek természetesen nem tekinthetőek új formáknak. Új forma - amely a COVID-19 koronavírus-járvány idején nyert teret mind a régebbi, mind pedig az újabb közösségek életében - azonban a Zoom és a többi, az interaktivitás - a hagyományos közvetítésen túlmutató érdemi bevonódást lehetővé tevő - új szintjét biztosító felület is. A nagyobb (tipikusan: hagyományos) egyházak és a kisebb közösségek, illetve újabb entitások tekintetében egyként igaz, hogy az egyik leglátványosabb változás a mediatizáció, médiajelenlét, közösségi médiahasználat megjelenése és gyorsuló terjedése. Ezek léte, tartalma, fejleszthetősége középponti témává vált a vallási hírmüsorokban és a tudományos elemzésekben is, sőt, az egyes denominációk stb. önreflexióiban, fejlesztési stratégiáiban is.

Azt látjuk továbbá, hogy az egyes vallási közösségek kapcsán is középponti témává válik az identitásépítés, -erősítés kérdése. Ez a leghagyományosabb közegekben is önálló kérdéssé válik, ${ }^{67}$ de az újabb törekvésekben is lényeges szerepet játszik. Azt is látjuk, hogy az identitásépítés, -erősítés és a meglévő identitás kifelé történő képviselete új formákat öltve jelenik meg: a legintenzívebb kortárs forma

\footnotetext{
${ }^{67}$ Simon Zoltán: „Etnikai, vallási identitás-konstrukciók egy középső-nyárádmenti görög katolikus kis közösség példáján keresztül.” Néprajzi Látóhatár, XIX, 2010/4, 4-44.
} 
az ún. fesztivalizáció mint törekvés, magatartásforma ${ }^{68}$ méghozzá a zene hagyományos szerepén jóval túlmutató módokon. ${ }^{69}$

A hazai szakirodalom is feltárja az „új vallási nyelv” keresésére való igény jelenlétét, ${ }^{70}$ mely szerint minden kornak meg kell találnia azt a megfelelö „nyelvet” - és tehetjük hozzá, csatornát -, melyen keresztül az egyház üzenete megértésre talál a hívek körében. A késő-modernitás körülményei között egyre fontosabb, hogy a fogyasztói- és élménytársadalom mechanizmusának megfelelve, a vallási élmény úgy is, mint a vallási piac sajátos terméke - maga is a tömegek igényeihez igazodva jelenik meg és válik tömegtermékké (is). „Ennek egyik megnyilvánulása a divat aktuális trendjeinek beszivárgása a liturgiába, többek között a keresztény könynyüzenén keresztül. Nemcsak arról van azonban szó, hogy a hasonló profán zenei divatot felhasználó különböző vallási csoportokban tapasztalható vallási élmény az alkalmazott zene miatt lenne hasonló, hanem arról is, hogy az adott vallási élményekhez ez a fajta zenei stílus illeszkedik jobban." ${ }^{11}$

Meg kell említenünk mindezek mellett, hogy a posztmodern kor jellemzőjeként meghatározott szigorú határok dekonstrukciója, a hierarchia és a különbségek hangsúlyozása helyett a partneri szemlélet preferálása a vallási kultúrában is megjelentek, és határozottan rányomták bélyegüket számos vallási közösségre, így például a hazai pünkösdi mozgalmakra is. A határok elmosódásának egyik leglátványosabb jele ma az egyes vallási elemek, gyakorlatok „felekezetközi vándorlása”. Ennek egyik korai formája volt a dalok terjedése, átszüremkedése a pünkösdizmus

\footnotetext{
${ }^{68}$ Somodi Éva: „A vallási fesztivalizáció jelensége. A szegedi zsidó közösség példái.” Szeged: várostörténeti, kulturális és közéleti magazin, XXIV, 2012/4, 34-37.

${ }^{69}$ Ehhez lásd például: Kinga Povedák: „Catholicism in Transition: The 'Religious Beat' Movement in Hungary." In Giselle Vincett - Elijah Obinna (szerk.): Christianity in the Modern World Changes and Controversies. Farnham, Ashgate, 2014, 1-22; Kinga Povedák: „Religion, Music, Community: The Interferences of the Pentecostal Charismatic Renewal and the Catholic Charismatic Renewal.' In Gábor Barna (szerk.): Religion, Culture, Society: Yearbook of the MTASZTE Research Group for the Study of Religious Culture. Szeged, MTA-SZTE Research Group for the Study of Religious Culture, 2014, 114-128, illetve ugyanez magyarul: Povedák Kinga: „Vallás, zene, közösség: A Pünkösdi Megújulás és a Katolikus Karizmatikus Megújulás interferenciái." In Barna Gábor - uő (szerk.): Lelkiségek, lelkiségi mozgalmak Magyarországon és Kelet-Közép Európában. Spirituality and Spiritual Movements in Hungary and Eastern Central Europe. Szeged, SZTE BTK Néprajzi és Kulturális Antropológiai Tanszék, 2014, 32-45.

${ }^{70}$ Morel Gyula: A jövő biztosabb, mint a múlt. Budapest, Egyházfórum Alapítvány, 1995. Idézi: Barna-Povedák (szerk.): Lelkiségek, 37.

${ }^{71}$ Uo.
} 
irányából a katolikus karizmatikusság ${ }^{72}$ szerveződései felé, ${ }^{73}$ és azon túl, a neoprotestáns stb. gyülekezetek irányában is!

Egyes kritikusai szerint az átvétel egyik negatív jellemzője (következménye), hogy a pünkösdi mozgalomtól átvett dalok egy része a pozitív keresztény üzenetet a fogyasztói kultúra értékrendszeréhez igazodó módon tálalja - a szenvedés teológiájától mentesen, a keresztet megkerülve, csak a feltámadás üzenetét közvetítve, a tömegkultúra divatos, intuitív zenei trendjeibe csomagolva. ${ }^{74}$

De nemcsak a technika vívmányai válhatnak a későmodernitás vallási praxisának részévé, hanem például a közgazdaságtudományból ismert branding vagy márkázás jelensége is. Mint ahogy a globalizáció előretörésével a termékek és szolgáltatások sikerében egyre fontosabb szerepet játszik az eredményes márkaépítés, úgy vallási területen is beszélhetünk egyfajta márkaépítésről. Erre a vallási brandingre vagy márkázásra nemzetközileg is jó példa a talán legnépszerübb pünkösdi karizmatikus dicsőítő csoport, a Hillsong Church, ${ }^{75}$ amelynek magyarországi jelenléte is egyre intenzívebb.

Az új vallási nyelv természetesen nem csupán a zene növekvő szerepét foglalja magában, de a társadalom megváltozott életvezetési, életviteli szokásaihoz igazodó, korábban említett „tanfolyami” jellegü vallásosság, és az azt állandósító, intézményesítő megoldások is ebbe a körbe sorolhatóak.

A további kutatások alkalmával önállóan is elemezhető/elemzendő kérdés lehet az ún. szabadkeresztény gyülekezetek müködési sajátosságainak jellemzése is; ${ }^{76}$

c) zárt, befelé irányuló tevékenységi formák is kialakultak. Ezek részben az a) és b) alpontokban jelzett tevékenységek adott közösségeken belüli formái, részben pedig olyan tevékenységek, melyek gyakran az önállósulás okaira is visszavezethetőek: a tanításbeli, rítusbeli, szervezeti, működési és egyéb kü-

\footnotetext{
${ }^{72}$ Karizma: szó szerint „kegyelmi adomány”, kettős értelemben is: mint a meg nem érdemelt üdvösség maga, s úgy is, mint Isten lelkének az egyes hívőre gyakorolt hatása. A karizma megjelenési módjai (kegyelmi vagy lelki ajándékok) elsősorban 1Kor 12-14-ben kerülnek megjelenítésre. Részletesebben lásd: K. Rahner - H. Vorgrimler: Teológiai kisszótár. Budapest, Szent István Társulat, 1980, 369-370. Ezen karizmák interpretációira jelen írásban nem térünk ki, jelen írás esetében megelégszünk a téma létének és jelentőségének rögzítésével.

${ }^{73}$ Barna-Povedák (szerk.): Lelkiségek, 38.

${ }^{74}$ Uo.

${ }^{75}$ Uo.

${ }^{76}$ Horváth Zsuzsa: „Egy szabadkeresztény gyülekezet.” In Csákó Mihály (szerk.): Hitek és emberek. Horváth Zsuzsa tanulmányai kisegyházakról, vallásos mozgalmakról. Budapest, Eötvös Loránd Tudományegyetem Szociológiai-Szociálpolitikai Intézete, 1995, 153-232.
} 
lönbségek érvényesítésére leginkább ezen belső, kifelé nem vagy csak részlegesen képviselt egyes meggyőződések, gyakorlatok, illetve hagyományok alapján kerül sor.

\section{III.2.1. A MEGÚJULÁS EGY LÉNYEGES SAJÁTOSSÁGA A NAGYOBB VALLÁSI KÖZÖSSÉGEK ESETÉBEN: A RESTITÚCIÓ ÉS ANNAK HATÁSAI}

A vallási megújulás - humán közszolgáltatási intézményrendszerben testet öltő újabb formáival szoros kapcsolatban áll az a tény is, hogy a rendszerváltozást követően az egyházak visszakapták ingatlanaik egy részét, a humán közszolgáltatások nyújtásának, a hitélet teljesen szabad szervezésének stb. lehetőségét, de ekkor a nekik adott ruha még túl bö volt rájuk: évtizedekbe telt, telik míg belenőnek azokba, az infrastruktúra müködtetésén túl a lelki típusú lehetőségeket is teljesebben kiaknázva, kihasználva, fejlesztve. A vallási élet természetes ciklusaiként értelmezhetjük azokat az egymásra épülő stációkat, mikor is előbb az egyházak visszakapják (megszerzik) egy-egy intézményüket, de a működés ténylegesen vallási szabályok általi meghatározottsága csak később (utóbb) teljesedik ki: egy hagyományos, nagyobb egyház által fenntartott intézményben eljutni oda, hogy az adott felekezet normái, együttélési szabályai valamennyi igénybevevőre és alkalmazottra (szolgálattevőre) ténylegesen kiterjesztésre kerüljenek, gyakran hosszú idő (és gyakran konfliktusoktól és fájdalmaktól sem mentes tanulási időszak). ${ }^{77}$ Azaz a fenntartó személyének meghatározása és a fenntartási feladatok ellátása önmagában még nem feltétlenül teszi müködővé és ténylegesen érvényesülővé a Biblia egyes alapelveit, a szeretet parancsából kibomló kívánalmak sorát...

Összefoglalva: a nagyobb (hagyományos) egyházak változási, átalakulási tendenciái mögött a hirtelen támadt szabadság sajátosságait (pluralizmus, jogállam, vallásszabadság, piacgazdaság, humán közszolgáltatások nyújtásának szabadsága, kárpótlás, vagyonrendezés, kiegészítő normatíva stb.) értelmező adaptációs időszak természetes problémái is jelen vannak.

${ }^{77}$ A kérdéskörhöz lásd Rixer Ádám: „A Biblia szövegeinek felhasználhatósága az egyházi fenntartású intézmények belső dokumentumaiban.” In Birher Nándor - Homicskó Árpád Olivér (szerk.): Az egyházi intézmények működtetésének etikai alapjai. Budapest, Károli Gáspár Református Egyetem Állam- és Jogtudományi Kara, 2019, 25-36. 


\section{BIBLIOGRÁFIA}

Andreescu, Gabriel: „Vallási élet Romániában: Semleges szabályozás, pártos gyakorlat.” Egyházfórum, XXXIII, 2018/2, 23-37.

Appleby, R. Scott: The Ambivalence of the Sacred: Religion, Violence, and Reconciliation. Lanham, MD., Rowman \& Littlefield Publishers, 2000.

Baer, H. David: „Lasst sie uns nach unserem Bilde machen! Wie durch Ungarns Religionsgesetz die religiöse Landschaft umgestaltet werden soll.” In Kai Funkschmidt (Hrsg.): Mit welchem Recht? Europäisches Religionsrecht im Umgang mit neuen religiösen Bewegungen. Berlin, EZW-Texte 234, 2014, 161-178.

Berger, Peter: „The Desecularization of the World: A Global Overview.” In uö (ed.): The Desecularization of the World: Resurgent Religion and World Politics. Grand Rapids, William B. Eerdmans Publishing Company, 1999, 1-18.

Cherribi, Sam: „Bad Faith: The Danger of Religious Extremism by Neil J. Kressel. Review.” Political Psychology, XXX, 2009/2, 319-323.

Cusack, Caroline M. - Kirby, Danielle L. (eds.): Sects, Cults, and New Religions. London, Routledge, 2014.

Czagány Gábor: „A református hagyományok, mint a társadalmi identitás kifejezőeszközei a Kárpát-medencében.” Deliberationes, IV, 2011/2, 49-72.

Csáji László Koppány: „How to Become Fundamentalist (A Hungarian charismatic prophet’s new religious movement in the Carpathian basin - an anthropological discourse analysis)." Sociology International Journal, II, 2018/3, 160-169.

Dobszay János: „Szakad a Hit Gyülekezete? Új szövetség.” HVG, XX, 1998/36, 92-99.

Fekete Péter: Az egyház és a szekta. Budapest, Magyarországi Református Egyház Kálvin János Kiadója, 1993.

Ferenczi Andrea: „Megmérni a mérhetetlent - a sémák és az istenkép összefüggései.” In Furkó Péter - Szathmári Éva (szerk.): Népszerü tudomány, tudománynépszerüsités, Studia Caroliensia. Budapest, KRE - L'Harmattan, 2019, 81-89.

Formicola, Jo Renee: „Recalibrating U.S. Catholic Church-State Relations: The Effects of Clerical Sexual Abuse." Journal of Church \& State, LVIII, 2016/2, 307-330.

Frivaldszky János: Jó kormányzás és a közjó politikai és jogfilozófiai szemszögböl. Budapest, Pázmány Press, 2016.

Fukuyama, Francis: A történelem vége és az utolsó ember. Ford. Somogyi Pál László. Budapest, Európa, 1994, 471.

Gergely András: „Kisebbségben: a »civil társadalom « másképp közelítése.” MASZOL, 2017. 07. 20., 172. maszol.ro/index.php/kisebbsegben/8358o-kisebbsegben-a-civil-tarsadalom-maskepp-kozelitese (2020.09. 05.).

Havasi Virág: „Keresztény új vallási és vallási megújulási mozgalmak Magyarországon 1945-től napjainkig." Egyháztörténeti Szemle, XIX, 2018/4, 106-119.

Havasi Virág: „Vallási körkép - A vallásosság alakulása itthon és külföldön.” In Szabó-Tóth Kinga Várhelyi Krisztina (szerk.): A történelmi egyházak - modern társadalom. Budapest, L’Harmattan, 2018, 5 .

Hegedűs Lóránt, id.: „A református ökumené szerepe a Kárpát-medencében.” Confessio: a Magyarországi Református Egyház figyelöje, XVII, 1993/3, 17-21.

Herbert Dóra: „Képek vagy rémképek”. SZEMlélek, 2020. szeptember 5., szombat 19:32, cimlap.blog. hu/\#bloghu/szemlelek/2020/o9/05/kepek_es_remkepek (2021. 01.17.). 
Hortobágyi Zoltán: „Papság, neurózis, vallási közösség. Beszélgetés Gyökössy Endre teológussal.” Magyar Szemle, IV, 1995/8, 839-842.

Horváth Zsuzsa: „Egy szabadkeresztény gyülekezet.” In Csákó Mihály (szerk.): Hitek és emberek. Horváth Zsuzsa tanulmányai kisegyházakról, vallásos mozgalmakról. Budapest, Eötvös Loránd Tudományegyetem Szociológiai-Szociálpolitikai Intézete, 1995, 153-232.

Iannaccone, Laurence R.: „Religious Extremism: Origins and Consequences.” Contemporary Jewry, XX, 1999/1, 8-29.

Kis-Benedek József: „Vallási szélsőségek a MENA-országokban.” Hadtudomány, XXIX, 2019/1-2, 61-84.

Kiss Dénes: „Deszekularizáció Romániában.” Korunk, XXV, 2014/5, 4-14.

Kopp Mária - Székely András - Skrabski Árpád: „Vallásosság és egészség az átalakuló társadalomban.” Mentálhigiéné és Pszichoszomatika, V, 2004/2, 103-125.

Köbel Szilvia: „Az Alkotmánybíróság vallásszabadsággal és vallási közösségekkel kapcsolatos gyakorlata." In uő (szerk.): Az állami és a felekezeti egyházjog alapjai. Budapest, Patrocinium, 2016, 207-234.

Kövér Ágnes: „Captured by Church and State: Civil Society in Democratic Hungary.” In P. Krasztev J. Van Til (eds.): Hungarian Patient. Budapest, CEU Press, 2015, 81-90.

Krystyna, Daniel - Durham, W. Cole: „A vallási azonosságtudat mint a nemzeti identitás összetevője.” Fundamentum, I, 1997/2, 3-14.

Lajtai Mátyás: „Magyarország vallási viszonyai a népszámlálások és egyéb lakossági adatfelvételek tükrében”. Statisztikai Szemle, XCVIII, 2020/6, 573-598.

Lánszki Béla: „A felszabadítási teológia ideje lejárt?” Credo - evangélikus folyóirat, V, 1999/3-4, 69-75.

Liebman, Charles S.: „Extremism as a Religious Norm.” Journal for the Scientific Study of Religion, XXII, 1983/1, 75-86.

Lugosi Győző: „Szekták, kultuszok, (már nem is annyira) új vallási mozgalmak... Szcientológia és globalizáció." Eszmélet, XXIX, 2017/2, 190-211.

Mártonffy Marcell: „A Magyarországi Evangéliumi Testvérközösség szolgálata.” Egyházfórum, XXXI, 2016/3, 3-16.

Martos Tamás - Kézdy Anikó: „Vallásosság, lelki egészség, boldogság.” In Horváth-Szabó Katalin (szerk.): Vallásosság és személyiség. Piliscsaba, PPKE, 2007, 51-83.

Máté-Tóth András - Nagy Gábor Dániel: „A 2011-es Népszámlálás vallási adatairól” Egyház és Társadalom, 2013. 04. 04. egyhazestarsadalom.hu/2013/04/04/mate-toth-andras-nagy-gabor-daniel-a-2011-es-nepszamlalas-vallasi-adatairol/ (2021. 01. 17.).

Máté-Tóth András: „Kirekesztés: avagy az erőszak vallási legitimációja.” In Szilágyi Tamás (szerk.): Vallás és erőszak: elméleti koncepciók és a globális terrorizmus felemelkedése a 21. században. Szeged, SZTE BTK Vallástudományi Tanszék, 2017, 4-21.

Maton, Kenneth I. - Wells, Elizabeth A.: „Religion as a Community Resource for Well-Being: Prevention, Healing, and Empowerment Pathways." Journal of Social Issues, LI, 1995/2, 177-193.

McPhillips, Kathleen: „The Church, the Commission and the Truth: Inside the NSW Special Inquiry into Child Sexual Abuse." Journal for the Academic Study of Religion, XXIX, 2016/1, 30-51.

Melucci, R.: „Social Movements and the Democratization of the Everyday Life.” In John Keane (ed.): Civil Society and the State. London - New York, Verso, 1988.

Morel Gyula: A jövő biztosabb, mint a múlt. Budapest, Egyházfórum Alapítvány, 1995.

Ormóshegyi Zoltán - Rixer Ádám: „Magyarországi vallási közösségek pénzügyi forrásai és gazdálkodása a jogi szabályozás tükrében." In Köbel Szilvia (szerk.): Az állami és a felekezeti egyházjog alapjai. Budapest, Patrocinium, 2016, 176-207. 
Povedák István: „Láthatatlan határok. A keresztény - újpogány szinkretizmus.” In uő - Szilárdi Réka: Sámán sámán hátán. A kortárs pogányság multidiszciplináris elemzése. Szeged, MTA-SZTE Vallási Kultúrakutató Csoport - SZTE Néprajzi és Kulturális Antropológiai Tanszék, 2014.

Povedák Kinga: „Catholicism in Transition: The 'Religious Beat' Movement in Hungary.” In Giselle Vincett - Elijah Obinna (eds.): Christianity in the Modern World - Changes and Controversies. Farnham, Ashgate, 2014, 1-22.

Povedák Kinga: „Religion, Music, Community: The Interferences of the Pentecostal Charismatic Renewal and the Catholic Charismatic Renewal." In Gábor Barna (ed.): Religion, Culture, Society: Yearbook of the MTA-SZTE Research Group for the Study of Religious Culture. Szeged, MTA-SZTE Research Group for the Study of Religious Culture, 2014, 114-128.

Povedák Kinga: „Vallás, zene, közösség: A Pünkösdi Megújulás és a Katolikus Karizmatikus Megújulás interferenciái." In Barna Gábor - úő (szerk.): Lelkiségek, lelkiségi mozgalmak Magyarországon és Kelet-Közép Európában. Spirituality and Spiritual Movements in Hungary and Eastern Central Europe. Szeged, SZTE BTK Néprajzi és Kulturális Antropológiai Tanszék, 2014, 32-45.

Prancz Zoltán: „Elvhűség és vallási türelem: Össze kell-e békíteni eszmeileg a vallásokat ahhoz, hogy követőik békében éljenek egymással?" Sola Scriptura, XXI, 2019/2, 17-20.

Radvánszky Ferenc: „Megtörő kegyelem. Avagy, a Kárpátaljai Református Egyház (KRE) előtt álló kihívások és látható irányai, különös tekintettel a KRE struktúrájára és demográfiai tendenciáira." Szellem és Tudomány, VIII, 2017/Klnsz., 195-214.

Rahner, K. - Vorgrimler, H.: Teológiai kisszótár. Budapest, Szent István Társulat, 1980.

Rajki Zoltán - Szigeti Jenő: Szabadegyházak története Magyarországon 1989-ig. Budapest, Gondolat, 2012.

Ratzinger, Joseph: Beszélgetés a hitröl Vittorio Messorival. Budapest, Vigilia, 1990, 151.

Rixer Âdám: „Állam, jog és törvény. Régi szereplők új szerepekben.” In Erdélyi László (szerk.): Egyházügyi, vallásszabadsági tudományos konferencia: Budapest, 2011. november 21. Budapest, Boldog Élet Alapítvány, 2011, 33-51.

Rixer Ádám: „A vallás fogalmáról” Jogelméleti Szemle, XIV, 2011/4, 1-8.

Rixer Ádám: „A hatásvizsgálatok jelentősége és egyes szempontjai a vallási szervezetek szabályozása körében." Kodifikáció, II, 2013/1, 89-101.

Rixer Ádám: „A történeti alkotmány vívmányai: Utazás a múltba vagy út a jövőbe?” Balogh Judit et al. (szerk.): 65. Studia in honorem István Stipta. Budapest, Károli Gáspár Református Egyetem Állam- és Jogtudományi Kar, 2017, 365-37.

Rixer Ádám: „Az állam és a vallási közösségek kapcsolata a mai Magyarországon. A vallási közösségek nyilvántartása és pénzügyei a jogi szabályozás tükrében." Államtudományi Mühelytanulmányok, I, 2017/1, 1-35, ezen belül 17 .

Rixer Ádám: A vívmány-teszt. Budapest, Dialóg Campus Kiadó, 2018.

Rixer Ádám: „A civil társadalom helyzete Magyarországon, különös tekintettel a populizmus térnyerésére." Glossa Iuridica, V, 2018/3-4, 43-72.

Rixer Ádám: „A vallási szélsőségek tipológiája Magyarországon.” Vallástudományi Szemle, XIV, 2018/5, 15-30.

Rixer Ádám: „The Typology of Religious Extremism.” Advances in Social Sciences Research Journal, V, 2018/12, 519-531.

Rixer Ádám: „A Biblia szövegeinek felhasználhatósága az egyházi fenntartású intézmények belső dokumentumaiban.” In Birher Nándor - Homicskó Árpád Olivér (szerk.): Az egyházi intézmények müködtetésének etikai alapjai. Budapest, Károli Gáspár Református Egyetem Állam- és Jogtudományi Kara, 2019, 25-36.

Rixer Ádám: „A keresztény szabadság jogi és teológiai fogalma.” Acta Humana, VIII, 2020/3, 139-168. 
Rixer Ádám: „A normativitás kezdetei. A járványok szerepe és kezelése az Ószövetségben.” Létünk (megjelenés elött).

Rosta Gergely: „Szekularizáció? Deszekularizáció? Merre tart a vallási változás a világban?” Magyar Tudomány, CLXXX, 2019/6, 792-803.

Simon Zoltán: „Etnikai, vallási identitás-konstrukciók egy középső-nyárádmenti görög katolikus kis közösség példáján keresztül." Néprajzi Látóhatár, XIX, 2010/4, 4-44.

Simon Zoltán: „Megjegyzések az erdélyi szabadegyházak, új vallási mozgalmak kutatásának margójára. A szektaképződés kérdésköre az antropológiai kutatás gyakorlatában.” Szellem és Tudomány, XI, 2020/Klnsz. 578-587.

Somodi Éva: „A vallási fesztivalizáció jelensége. A szegedi zsidó közösség példái” Szeged: várostörténeti, kulturális és közéleti magazin, XXIV, 2012/4, 34-37.

Stark, Rodney - Bainbridge, S. William: The Theory of Religion. New York, Peter Lang, 1987.

Sz. N.: „Bátor szembenézés: Hatékony fellépés a gyermekek szexuális kihasználóival szemben.” Korunk, XXIII, 2012/4, 99-106.

Szabó Ferenc: „Keresztény hitünk a vallási pluralizmus korában.” Egyházfórum, XXXIII, 2018/2, 1-14. Szentmártoni Mihály: „A felnőttkor vallásossága”. Magyar Pszichológiai Szemle, LVIII, 2003/1, 65-81.

Tomka Miklós: Vallás és társadalom Magyarországon. Budapest-Piliscsaba, Loisir Kft., 2006.

Török Péter: És (a)mikor destruktívak? Az új vallási mozgalmak szociológiája és hazai helyzete. Budapest, SOTE, 2007.

Tuskhova, Julia Valerijevna: „ISIS and Al-Qaeda as the Determinants of Religious Extremism in the UK." Society: Politics, Economics, Law, XIV, 2017/8, 1-4.

Uitz Renáta: „Lelkiismereti és vallásszabadság a multikulturális Európában. Hogyan tovább? Hova tovább?" Jogtudományi Közlöny, LXXIV, 2019/5, 213-228.

Van Uchelen, Collin: „Individualism, Collectivism, and Community Psychology.” In Julian Rappaport - Edward Seidman (eds.): Handbook of Community Psychology. New York, Springer Science, 2000, 65-78. 